\title{
Study of the Contribution of Active Defense Mechanisms to Ciprofloxacin Tolerance in Escherichia Coli Growing at Different Rates
}

Galina Smirnova ( $\square$ smirnova@iegm.ru )

Institute of Ecology and Genetics of Microorganisms https://orcid.org/0000-0001-6116-8147

\section{Aleksey V. Tyulenev}

Institute of Ecology and Genetics of Microorganisms

Nadezda G. Muzyka

Institute of Ecology and Genetics of Microorganisms

Oleg N. Oktyabrsky

Institute of Ecology and Genetics of Microorganisms

\section{Research Article}

Keywords: Ciprofloxacin, Glutathione, Membrane potential, Hydrogen sulfide, ompF, rpoS, tolC and recA knockouts, Respiration, Specific growth rate

Posted Date: July 30th, 2021

DOI: https://doi.org/10.21203/rs.3.rs-703156/v1

License: (c) (i) This work is licensed under a Creative Commons Attribution 4.0 International License. Read Full License

Version of Record: A version of this preprint was published at Antonie van Leeuwenhoek on January 13th, 2022. See the published version at https://doi.org/10.1007/s10482-021-01693-6. 


\section{Abstract}

Using rpoS, tolC, ompF, and recA knockouts, we investigated their effect on the physiological response and lethality of ciprofloxacin in E. coli growing at different rates on glucose, succinate or acetate. We have shown that, regardless of the strain, the degree of changes in respiration, membrane potential, NAD/NADH ratio, ATP and glutathione (GSH) strongly depends on the initial growth rate and the degree of its inhibition. The deletion of the regulator of the general stress response RpoS, although it influenced the expression of antioxidant genes, did not significantly affect the tolerance to ciprofloxacin at all growth rates. The mutant lacking TolC, which is a component of many $E$. coli efflux pumps, showed the same sensitivity to ciprofloxacin as the parent. The absence of porin OmpF slowed down the entry of ciprofloxacin into cells, prolonged growth and shifted the optimal bactericidal concentration towards higher values. Deficiency of RecA, a regulator of the SOS response, dramatically altered the late phase of the SOS response (SOS-dependent cell death), preventing respiratory inhibition and a drop in membrane potential. The recA mutation inverted GSH fluxes across the membrane and abolished ciprofloxacininduced $\mathrm{H}_{2} \mathrm{~S}$ production. At all growth rates, this mutation reduced logCFU ml${ }^{-1}$ by about 3 orders of magnitude. All studied mutants showed an inverse linear relationship between logCFU $\mathrm{ml}^{-1}$ and the specific growth rate, that is, the activity of antibiotic targets. Mutations shifted the plot of this dependence relative to the parental strain according to their significance for ciprofloxacin tolerance.

\section{Introduction}

An in-depth understanding of the physiological response of microorganisms to antibiotic stress and the mechanisms for killing bacteria can be the basis for finding ways to increase the efficiency of existing and new antibiotics and prevent the emergence of antibiotic-resistant strains of microorganisms. It is well known that a susceptibility of bacteria to antibiotic-mediated killing is strongly affected by their growth rate. Drug tolerance increases with decreasing growth rates and reduces to a minimum in fast growing cultures (Tuomanen et al. 1986; Eng et al. 1991; Sufya et al. 2003; Greulich et al. 2015; Lee et al. 2017; Smirnova and Oktyabrsky 2018; Pontes and Groisman 2019). We have recently shown that an increase in the specific growth rate $(\mu)$ by $0.1 \mathrm{~h}^{-1}$ leads to an increase in the ciprofloxacin-induced killing rate by about $1 \mathrm{~h}^{-1}$, regardless of the reasons affecting the growth rate (medium composition, temperature, pretreatment with various reagents, or mutations) (Smirnova and Oktyabrsky 2018). The specific growth rate can be considered as an integral parameter reflecting the activity of interrelated core cellular processes (chromosome replication, transcription, and translation) and, accordingly, the number of active targets for antibiotics with different types of action (Pontes and Groisman 2020). Target inactivity could block antibiotic action. However, simultaneously with a change in the number of targets, a change in the growth rate is accompanied by metabolic reprogramming under complex regulatory control by signal transduction factors and regulators, including guanosine tetraphosphate (p)ppGpp and the regulator of the general stress response RpoS $\left(\sigma^{S}\right)$ (Steinchen and Bange 2016). The levels of both (p)ppGpp and RpoS are inversely related to the growth rate, increasing linearly with decreasing $\mu$ (Potrykus et al. 2011; Ihssen and Egli 2004). RpoS controls the expression of many proteins involved in the protection of vital 
biomolecules, i.e., proteins, DNA, and the cell envelope, which provides a high level of resistance of stationary-phase cells to various stresses, including osmotic shock, oxidative stress, heat shock, and acid and base shock (Matin 1991; Hengge 2008; Navarro Llorens et al. 2010; Mitchell et al. 2017). In addition, it has been shown that the composition of the medium and the growth rate of bacteria can affect the activity of multidrug efflux pumps, in particular AcrAB-TolC (Rand et al. 2002; Bailey et al. 2006). An increase in the (p)ppGpp level may be accompanied by the induction of the SOS response (Maslowska et al. 2019). Therefore, there is a possibility that differences in the activity of bacterial defense systems associated with a change in the growth rate will make some contribution to the development of antibiotic tolerance in addition to a change in the activity of specific targets. In many previous works, the role of defense systems in the development of tolerance to antibiotics was studied in cells in the stationary phase or exposed to stress, as well as in the context of studying the mechanisms of persistence (Hansen et al. 2008; Fung et al. 2010; Nguyen et al. 2011; Amato et al. 2013; Theodore et al. 2013; Pu et al. 2016; Radzikowski et al. 2016; Kaldalu et al. 2020). The aim of this work was to study the role of defense mechanisms in response to antibiotic stress and in the development of tolerance to ciprofloxacin in $E$. coli growing at different rates. Variation in specific growth rates was achieved by growing bacteria on different sources of carbon and energy (glucose, sodium succinate, and sodium acetate).

Fluoroquinolone ciprofloxacin kills bacteria by damaging their DNA through interaction with gyrase and topoisomerase IV, eventually leading to chromosome fragmentation and cell death (Bush et al. 2020). It is assumed that reactive oxygen species (ROS) are involved in the mechanism of quinolone-mediated rapid killing (Hong et al. 2020). However, the exact mechanisms that lead to bacterial death, especially the role of ROS in lethality, require further study. Quinolone-induced DNA damage activates the RecA/LexAcontrolled SOS gene network, resulting in the production of various repair proteins and contributing significantly to ciprofloxacin tolerance (Theodore et al. 2013). The concentration of ciprofloxacin in E. coli cells depends on the activity of its entry through the OmpF porin (Hirai et al. 1986) and its pumping out with the participation of bacterial efflux pumps (mainly AcrAB), the central component of which is the outer membrane efflux protein TolC (Goswami et al. 2016). To study the role of the SOS response and other stress responses in tolerance to ciprofloxacin at different growth rates, mutants with deletions of the recA, rpoS, ompF, and tolC genes were used.

\section{Materials And Methods}

Strains and growth conditions

A parental strain of Escherichia coli BW25113 (wt) and single-knockout mutants JW2669 ( $\triangle \mathrm{rec} A)$,

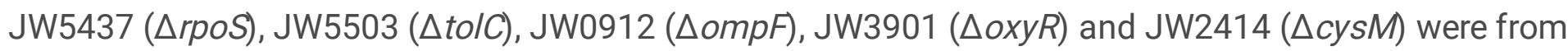
the Keio collection (Baba et al. 2006). The strains carrying transcriptional gene fusions katG::/acZ and $k a t E:: / a c Z$ were constructed by transformation of the parental strain and the rpoS mutant with plasmids pKT1033 and pRS katE16, respectively (Tao et al. 1989; Mulvey et al. 1990). The strains with sodA::/acZ and sulA(sfiA)::/acZ fusions were created by P1 transduction from the strains QC772 and DM4000, respectively (Carlioz and Touati 1986; Volkert et al. 1989). 
Night cultures $(100 \mathrm{ml})$ were grown with shaking (150 rpm) in M9 minimal medium with $10 \mathrm{mM}$ of glucose, sodium succinate or sodium acetate at $37^{\circ} \mathrm{C}$ (Miller 1972). After centrifugation, these cells were resuspended in $100 \mathrm{ml}$ of fresh medium to $\mathrm{OD}_{600}$ of 0.1 and then grown as described above. In mid-log phase $\left(\mathrm{OD}_{600}\right.$ of 0.4$)$ bacteria were treated with $0.3(20 \times \mathrm{MIC})$ or $3 \mu \mathrm{g}$ ciprofloxacin (CF) $\mathrm{ml}^{-1}$ and growth was monitored for $2-2.5$ hours. The specific growth rate $(\mu)$ was calculated by equation $\mu=\Delta \ln O D_{600} /$ $\Delta \mathrm{t}$, where $t$ is the time in hours.

Real-time monitoring of dissolved oxygen $\left(\mathrm{dO}_{2}\right), \mathrm{pH}$, and extracellular sulfide $\left(\mathrm{S}^{2-}\right)$

Dissolved oxygen and $\mathrm{pH}$ in $E$. coli cultures were continuously measured directly in the flasks using a Clarke oxygen electrode InPro 6800 (Mettler Toledo) and a pH electrode Expert ProlSM (Mettler Toledo), respectively. The $\mathrm{dO}_{2} / \mathrm{pH}$ controller of BioFlo 110 fermentor (New Brunswick Scientific Co., USA) was used for data recording. Ciprofloxacin was added without stop of rotation of flasks.

Extracellular sulfide was also detected directly in the flasks using the system of sulfide-specific ionselective XC-S ${ }^{2-}-001$ (Sensor Systems Company, Russia) and reference electrodes and a computer $\mathrm{pH} / \mathrm{ion}$ meter cpX-2 (IBI Pushchino, Russia). All parameters were continuously and synchronously processed in real time using a single hardware-software complex, including several registration units.

\section{Determination of $\mathrm{ATP}$ and $\mathrm{NAD}^{+} / \mathrm{NADH}$ ratio}

ATP concentration was measured using the luciferin-luciferase ATP determination kit (Molecular Probes). For ATP extraction, $50 \mu$ l of the cell suspension was mixed with $450 \mu$ l of cell disruption reagent (DMSO). The extraction was completed within 5 min and the ATP concentration was determined according to the manufacturer's protocol.

NAD-NADH pool was determined as described previously (Leonardo et al. 1996). Duplicate 1.0-ml samples were placed in Eppendorf tubes and centrifuged at $15000 \mathrm{~g}$ for $1 \mathrm{~min}$. After removal of the supernatant, the pellets were immediately frozen and then $250 \mu$ of either $0.2 \mathrm{M} \mathrm{HCl}$ (for NAD extraction) or $0.2 \mathrm{M} \mathrm{NaOH}$ (for NADH extraction) were added to the frozen pellets. Specific dinucleotides were extracted for $10 \mathrm{~min}$ at $100^{\circ} \mathrm{C}$ in a Thermo-Shaker TS-100C (BioSan, EU) and then the tubes were centrifuged at $5000 \mathrm{~g}$ for 5 min to remove cellular debris. Assay of the extracts containing specific dinucleotide species were performed in triplicate by the recycling assay as previously described (Leonardo et al. 1996). Coenzyme standards from 1.5 to $0.05 \mu \mathrm{M}$ were used to calibrate the assay.

Study of cell viability and membrane potential

For colony-forming studies, culture samples were washed, diluted in $0.9 \% \mathrm{NaCl}$, mixed with molten soft LB-agar ( $0.8 \%)$ at $42^{\circ} \mathrm{C}$ and poured onto plates with solid LB-agar (1.5\%). Colonies were counted over 24hour incubation at $37^{\circ} \mathrm{C}$. 
Changes in the membrane potential $(\Delta \psi)$ were evaluated using $\Delta \psi$-sensitive fluorescent dye $\operatorname{DiBAC}_{4}(3)$ (Wickens et al. 2000) as described previously (Smirnova et al. 2015). Samples of log-phase cells treated with the protonophore carbonylcyanide $m$-chlorophenylhydrasone (CCCP, $20 \mu \mathrm{M}$ ) were used as positive control. Fluorescent cells were counted using Leica DM2000 microscope as earlier described (Smirnova et al. 2015). Total cell number was counted in transmitted light. About 1000 cells were counted for every sample and all experiments were conducted 3-6 times on separate days.

Measurement of extracellular superoxide and $\mathrm{H}_{2} \mathrm{O}_{2}$

Extracellular superoxide was monitored by the method (Korshunov and Imlay 2006) using the ability of superoxide to reduce ferricytochrome $c$. Cells were grown in M9 medium with glucose, succinate or acetate to $\mathrm{OD}_{600}$ of 0.5 , centrifuged and resuspended to $\mathrm{OD}_{600}$ of 0.2 in three 50 -ml flasks containing 12 $\mathrm{ml}$ of prewarmed medium. One of these flasks was used to growth monitoring. Two other flasks additionally contained $20 \mu \mathrm{M}$ cytochrome $c$. Superoxide dismutase (SOD) $\left(30 \mathrm{U} \mathrm{ml}^{-1}\right)$ was added to one of two flasks, and they were incubated at $37^{\circ} \mathrm{C}$ with shaking at $150 \mathrm{rpm}$ for 2.5 hours. At 30 -min intervals, samples $(1.5 \mathrm{ml})$ were withdrawn, passed through membrane filters, and the reduced cytochrome $c$ was immediately determined as described in the method (Korshunov and Imlay 2006). The difference between the concentrations of reduced cytochrome $c$ in the flasks with and without SOD is equivalent to the concentration of extracellular superoxide.

For $\mathrm{H}_{2} \mathrm{O}_{2}$ determination, cells were grown as described in growth conditions. At intervals, 2-ml aliquots of culture were removed, passed through membrane filters and $\mathrm{H}_{2} \mathrm{O}_{2}$ was measured by Amplex Redhorseradish peroxidase detecting system (AR/HRP) (Seaver and Imlay 2001) using spectrofluorimeter Shimadzu RF-1501 (Shimadzu, Japan) ( $\lambda_{\mathrm{ex}} 563 \mathrm{~nm}$ and $\lambda_{\mathrm{em}} 587 \mathrm{~nm}$ ). The concentration of $\mathrm{H}_{2} \mathrm{O}_{2}$ in the samples was calculated from the calibration curve.

Determination of glutathione and $\beta$-galactosidase activity

Extracellular glutathione ( $\left.\mathrm{GSH}_{\text {out }}\right)$ was determined in samples, which were removed at 15 -min intervals by rapid filtration through $0.45 \mu \mathrm{m}$-pore-size filters. For the determination of intracellular glutathione $\left(\mathrm{GSH}_{\mathrm{in}}\right)$, $5 \mathrm{ml}$ samples of cell culture was harvested by centrifugation $(8000 \times g$ for $5 \mathrm{~min})$ at different time points and prepared as described previously (Smirnova et al. 2012). GSH was measured using the DTNBglutathione reductase recycling method (Tietze 1969) modified as described previously (Smirnova et al. 2012).

Changes in the expression of the tested genes were estimated by determination of $\beta$-galactosidase activity (Miller 1972) in E. coli strains carrying the appropriate gene fusions.

Determination of ciprofloxacin concentration in the growth medium

Changes in ciprofloxacin concentration in growing cultures were determined by its fluorescence $\left(\lambda_{\mathrm{ex}} 271\right.$ $\mathrm{nm}$ and $\lambda_{\mathrm{em}} 416 \mathrm{~nm}$ ) in samples taken through a membrane filter using a Shimadzu RF-1501 
spectrofluorimeter (Shimadzu, Japan). Since substances absorbing at $270 \mathrm{~nm}$ accumulate in the medium with increasing culture density, a series of calibration curves were created for different $\mathrm{OD}_{600}$ values. For this purpose, ciprofloxacin at concentrations of $0,0.3,0.6,1.2,1.5$, and $3 \mu \mathrm{g} \mathrm{ml}^{-1}$ was added to the filtrates obtained at different $\mathrm{OD}_{600}$ from control cultures, and fluorescence was determined. The concentration of ciprofloxacin in the test samples was determined by calibrations performed for the corresponding value of $\mathrm{OD}_{600}$.

Statistical analysis of the data

Each result is indicated as the mean value of three to six independent experiments \pm the standard error of the mean (SEM). Significant difference was analyzed by Student's t-test. A P-value of 0.05 was used as the cut-off for statistical significance. Results were analyzed by means of the program packet Statistica 6 (StatSoft Inc. 2001).

\section{Results}

Changes in the growth rate and energy parameters of cells

Mutants lacking the $r p o S$, recA, ompF and tolC genes grew at the same rate, approximately $0.68 \mathrm{~h}^{-1}$, as the parent when glucose was used as a substrate (Fig. 1a). Growing all strains on less energetically efficient succinate and acetate reduced the specific growth rate by 1.5 and 3.6 times, respectively. Interacting with DNA gyrase, ciprofloxacin inhibits replication and transcription, which leads to a decrease in the growth rate. The effect on growth rate was less pronounced at $0.3 \mu \mathrm{g} \mathrm{CF} \mathrm{ml}^{-1}$, where there was a 30-minute delay in the fall of $\mu$, while when using $3 \mu \mathrm{g} \mathrm{CF} \mathrm{ml}^{-1}$, the growth rate began to decrease immediately after its addition in all strains studied, except $\operatorname{ompF}$ (Fig. 1b, c, d). For both concentrations of ciprofloxacin, the antibiotic effect on growth decreased with a decrease in the initial growth rate and was minimal in cultures grown on acetate. The absence of porin OmpF significantly slowed down the ciprofloxacin-induced decrease in $\mu$ during growth on glucose and succinate compared to the parent, which apparently reflects a decrease in the intensity of antibiotic entry into cells in this mutant (Fig. 1d). Indeed, measurements showed that the decrease in the concentration of ciprofloxacin in the medium of the parental strain growing on glucose was 2.4 times faster than in the ompF mutant (Fig. 1S). The recA mutation did not affect the growth rate changes induced by $0.3 \mu \mathrm{g} \mathrm{CF} \mathrm{ml}^{-1}$ (Fig. 1b). However, unlike the parent, recA deficiency prevented the specific growth rate from falling below zero after 90 minutes of exposure to $3 \mu \mathrm{g} \mathrm{CF} \mathrm{ml}^{-1}$ (Fig. 1c). The absence of the rpoS and tolC genes did not significantly affect the growth rate in the presence of both antibiotic concentrations.

In our previous work, we showed that ciprofloxacin induces phase alterations in $E$. coli respiration during growth in a minimal medium with glucose: the first phase strongly depends on antibiotic concentration; the second phase is SOS-dependent (Smirnova et al. 2017). In the current study, dissolved oxygen $\left(\mathrm{dO}_{2}\right)$ was continuously measured directly in cultures grown with glucose, succinate and acetate. Despite the constant rotation of the flasks, the concentration of dissolved oxygen in untreated cultures gradually 
decreased due to an increase in oxygen consumption with an increase in biomass (control curves in Fig. 2a, b). The rate of this decrease, expressed as $\mathrm{dO}_{2} / \mathrm{OD}_{600} \bullet \min$, was $1.12 \pm 0.04,0.66 \pm 0.01$ and $0.16 \pm 0.01$ for glucose, succinate and acetate, respectively. The lower basal level of $\mathrm{dO}_{2}$ in cultures growing with succinate (Fig. 2a, b) is explained by a sharp decrease in $\mathrm{dO}_{2}$ by $30 \%$ within 10 minutes after the inoculum was added to the medium with succinate. The effect of ciprofloxacin on $\mathrm{dO}_{2}$ depended on both the type of growth substrate and the concentration of the antibiotic and correlated with its effect on the growth rate. After treating wild-type cells with $0.3 \mu \mathrm{g} \mathrm{CF} \mathrm{ml}^{-1}, \mathrm{dO}_{2}$ continued to decline over approximately 40, 60 and 90 minutes in E. coli grown with glucose, succinate and acetate, respectively (Fig. 2a). In the case of acetate, even a slight acceleration of oxygen consumption was observed in comparison with the control. After 80 min exposure to $0.3 \mu \mathrm{g} \mathrm{CF} \mathrm{ml}^{-1}$, an increase in $\mathrm{dO}_{2}$ was observed in cultures grown with glucose and succinate (Fig. 2a). This phase was SOS-dependent and did not occur in the recA mutant (Fig. 2b). Cultures grown on succinate and acetate did not show a phase of a sharp increase in $\mathrm{dO}_{2}$ immediately after treatment with $3 \mu \mathrm{g} \mathrm{CF} \mathrm{ml}^{-1}$, which is a characteristic feature of a culture grown on glucose and corresponds to a sharp inhibition of growth. The SOS-dependent phase of respiration inhibition by $3 \mu \mathrm{g} \mathrm{CF} \mathrm{ml}{ }^{-1}$ in cultures grown on succinate and acetate was more gradual than in cultures grown on glucose (Fig. 2a, b).

Metabolic shifts caused by ciprofloxacin can also be monitored using continuous, sensitive pH recording. The consumption of the substrate was accompanied by acidification of the medium due to the accumulation of acid by-products during growth on glucose, while alkalisation of the medium occurred during growth on succinate and acetate (Fig. 2S). Ciprofloxacin dose-dependently suppressed glucose consumption, but the consumption of acetate and succinate continued at a rate that did not differ significantly from the control. Interestingly, despite the same growth rate as the wild type, the recA mutant showed lower substrate consumption (Fig. 2S-b) as well as a slower decrease in $\mathrm{dO}_{2}$ during growth on all studied substrates (Fig. 2b).

To determine the ability of cells to maintain membrane potential, we used the fluorescent dye $\mathrm{DiBAC}_{4}(3)$, which stains only depolarized cells (Wickens et al. 2000). The percentage of depolarized cells in untreated cultures was higher during growth on succinate and acetate, $2.7 \pm 0.1$ and $2.2 \pm 0.1$, respectively, compared to $0.9 \pm 0.1$ during growth on glucose. Cultures exposed to $3 \mu \mathrm{g} \mathrm{CF} \mathrm{ml}^{-1}$ maintained the level of depolarized cells below $10 \%$ for an hour, but then there was a rapid decrease in membrane potential (Fig. 2c). In accordance with our previous work (Smirnova et al. 2017), this phase was SOS-dependent and coincided with the SOS-dependent phase of respiratory inhibition. The percentage of depolarized cells was 5 times lower in the recA mutant compared to the parental strain, when both grow on glucose (Fig. 2c). Wild-type cells growing on glucose lost $\Delta \psi 2$ times faster than cells growing on succinate and acetate (Fig. 2c), indicating more severe damage under conditions that provide a higher growth rate. Treatment with chloramphenicol $\left(25 \mathrm{\mu g} \mathrm{ml}^{-1}\right)$ or a bacteriostatic dose of $\mathrm{H}_{2} \mathrm{O}_{2}(2$ $\mathrm{mM}$ ) caused small changes (below $4 \%$ ) in $\Delta \psi$, while the use of a bactericidal dose of $\mathrm{H}_{2} \mathrm{O}_{2}(10 \mathrm{mM}$ ) led to the appearance of a phase of rapid decrease in the membrane potential (Fig. 2d). These data show 
that bacteriostatic drugs do not induce the late phase of the SOS response, in which the loss of membrane potential is one of the main features (Erental et al. 2014).

The growth rate of bacteria is largely determined by the rate of production of NADH, which is a source of reducing equivalents in the respiratory chain for creating an electrochemical proton gradient and ATP synthesis with the participation of ATP synthase. The steady-state level of NADH, which results from its production and consumption, was even lower and, accordingly, the NAD $/ \mathrm{NADH}$ ratio was higher in cells growing on glucose than in cells growing on succinate and acetate (Fig. 3a). 20 min after the addition of $3 \mu \mathrm{g} \mathrm{CF} \mathrm{ml}^{-1}$, there was a decrease in NADH and a 2-fold increase in the NAD $/ \mathrm{NADH}$ ratio in comparison with the untreated culture on glucose, while the level of NADH on succinate increased 1.7 times (Fig. 3a, b). No changes in these parameters were observed on acetate. Intracellular ATP increased after ciprofloxacin treatment in a dose-dependent manner (Fig. 3c). For all substrates, this increase was gradual at $0.3 \mu \mathrm{g} \mathrm{CF} \mathrm{ml}^{-1}$ and, conversely, quickly peaked at $3 \mu \mathrm{g} \mathrm{ml}^{-1}$ (Fig. 3d), which coincided with the growth inhibition mode at various concentrations of ciprofloxacin (Fig. 1b, c). The recA mutant showed the same mode of ATP changes as the parental strain (Fig. 3d).

Changes in the redox state of cells growing with various sources of carbon and energy

In our previous work, we showed that after a 20-min exposure, ciprofloxacin reduced both the production of extracellular superoxide and the level of extracellular $\mathrm{H}_{2} \mathrm{O}_{2}$, but significantly increased the level of intracellular $\left(\mathrm{GSH}_{\text {in }}\right)$ and extracellular glutathione $\left(\mathrm{GSH}_{\text {out }}\right)$ in cells growing on glucose (Smirnova et al. 2017). Growing on succinate had no effect on ROS generation compared to glucose, while the use of acetate reduced superoxide production by 1.5 times and the concentration of $\mathrm{H}_{2} \mathrm{O}_{2}$ in the medium by 2.2 times (Fig. 3S). The basal level of $\mathrm{GSH}_{\text {in }}$ was 1.3 times lower for succinate and 1.4 times higher for acetate as compared to cells grown on glucose (Fig. 4a). With all substrates, the intracellular glutathione level gradually increased during the observation period. In untreated cells, about $10 \%$ of the total synthesized glutathione was excreted into the medium, where its concentration per biomass unit was maintained at an approximately constant level (Fig. 4b).

Treatment with $3 \mu \mathrm{g} \mathrm{CF} \mathrm{ml}^{-1}$ caused a transient increase in $\mathrm{GSH}_{\text {in }}$ level that was proportional to the degree of growth inhibition and had significantly lower amplitude in cells growing on acetate and succinate compared to glucose (Fig. 4a). The increase in the level of $\mathrm{GSH}_{\text {in }}$ was accompanied by an increase in its extracellular concentration, which was higher for glucose and succinate than for acetate (Fig. 4b). The release of glutathione was especially accelerated after 60 min of exposure to ciprofloxacin. This phase coincided with a drop in the intracellular GSH and phases of SOS-dependent inhibition of respiration and rapid decrease in membrane potential (Fig. 2a, c). To clarify the role of the SOS-response in altering glutathione levels, we measured intracellular and extracellular glutathione in the recA mutant. Unexpectedly, an inversion of GSH levels inside and outside the cells was observed: $\mathrm{GSH}_{\text {in }}$ was low and stable during observation, while $\mathrm{GSH}_{\text {out }}$ was 4.5 times higher and gradually increased with increasing 
biomass (Fig. 4c). That is, most of the glutathione in this mutant left the cells as it was synthesised. The addition of $3 \mu \mathrm{g} \mathrm{CF} \mathrm{ml}^{-1}$ did not change the level of $\mathrm{GSH}_{\mathrm{in}}$, but accelerated its release into the medium.

Thus, ciprofloxacin provokes an acceleration of GSH synthesis in wild-type and mutant cells, which is apparently associated with a sharp inhibition of protein synthesis and transient excess of cysteine, which is a limiting component for GSH synthesis in a minimal medium. We have previously shown that this behavior of glutathione is characteristic of the inhibition of protein synthesis by valine and chloramphenicol, where GSH serves as a buffer for the bulk of excess cysteine (Smirnova et al. 2019). Simultaneously with an increase in glutathione production, a sharp inhibition of protein synthesis leads to an abrupt release of sulfide into the medium. Only a large dose of ciprofloxacin $\left(3 \mu \mathrm{g} \mathrm{ml}^{-1}\right)$ caused the release of $\mathrm{H}_{2} \mathrm{~S}$ in $E$. coli growing on glucose (Tyulenev et al. 2018). However, this dose of ciprofloxacin did not induce $\mathrm{H}_{2} \mathrm{~S}$ release when cells were grown on succinate or acetate (Fig. $4 \mathrm{~d}$ ). As in the case of valine and chloramphenicol (Smirnova et al. 2019), $\mathrm{H}_{2} \mathrm{~S}$ generation under exposure of $E$. coli to ciprofloxacin depended on the activity of cysteine synthase B (CysM) and was absent in the cysM mutant (Fig. 4e). $\mathrm{H}_{2} \mathrm{~S}$ production was also absent in the recA mutant (Fig. 4e). It was previously reported that $\mathrm{H}_{2} \mathrm{~S}$ can protect cells against antibiotic killing (Shatalin et al. 2011). To clarify this possibility under our conditions, we studied the effect of ciprofloxacin on the growth rate and the number of CFU in the cysM mutant with abolished $\mathrm{H}_{2} \mathrm{~S}$ production. No significant differences were found between the wild-type strain and the cysM mutant (Fig. 4S).

Expression of antioxidant genes in E. coligrowing with various carbon and energy sources

Several groups have shown a correlation between quinolone lethality and the accumulation of ROS (reviewed by Bush et al. 2020). When ROS accumulate in the cell, bacteria respond through the OxyR, SoxRS and RpoS regulons, which control the transcription of genes encoding ROS-scavenging enzymes (Imlay 2013). The expression of genes katG and katE, encoding catalases HPI (KatG) and HPII (KatE), is also positively regulated by RpoS (Ivanova et al. 1994), the level of which is inversely proportional to the specific growth rate (Ihssen, Egli 2004). In accordance with these data, in our experiments, the expression of katG::/acZ increased 1.4 and 2.3 times with growth on succinate and acetate, respectively, compared with glucose (Fig. 5a). Under the same conditions, the expression of katE::/acZ increased 1.8 and 2.1 times (Fig. 5b). The dependence of the expression of both genes on the type of substrate and thus on the growth rate was sharply reduced in the rpoS mutant (Fig. 5a, b). The expression of the sulA gene, which is controlled by SOS-regulon, also increased with a decrease in the growth rate of the culture in the sequence: glucose, succinate, acetate (Fig. $5 \mathrm{c}$ ). This growth rate dependence of sulA expression may be caused by an increase in the level of (p)ppGpp in slower growing cells, which leads to the induction of genes involved in the SOS response, as shown for the $E$. coli stringent response (Durfee et al. 2008). The rpoS mutation did not significantly affect the expression of sulA::lacZ during growth on glucose, but additionally increased it by 1.7 and 2.4 times on succinate and acetate, respectively. RpoS is known to positively regulate DNA polymerases II ( $p o / B)$ and IV (DinB) independently of LexA (Maslowska et al. 
2019); therefore, additional induction of the SOS response in the rpoS mutant may be a compensatory mechanism for maintaining their required level.

We have previously shown that the expression of the antioxidant genes $\operatorname{sod} A$ and $k a t G$, as well as the level of total catalase activity, significantly decreased during the action of ciprofloxacin on $E$. coli growing in a minimal medium with glucose (Smirnova et al. 2017). Ciprofloxacin treatment of cells growing on succinate or acetate also resulted in a decrease in katG::/acZ expression (Fig. $5 \mathrm{~d}$ ), while an increase in its expression in response to $\mathrm{H}_{2} \mathrm{O}_{2}$ addition was observed on all substrates (Fig. 5S). During growth on acetate, the expression of the sodA gene was 1.2 times higher than on glucose and succinate, and was maintained approximately constant in untreated culture (Fig. 5e). The higher basal level of $\operatorname{sod} A$ expression during growth on acetate, apparently, is a consequence of the removal of the repression of this gene by the $A r c A B$ regulatory system under conditions of an increased level of $\mathrm{dO}_{2}$ (Compan and

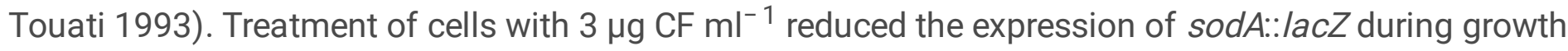
on all tested substrates. The effect of ciprofloxacin on the expression of the katE gene was proportional to the degree of growth inhibition by the antibiotic: it increased with an increase in the concentration of ciprofloxacin and with the transition to a more energy-efficient substrate. The addition of $3 \mu \mathrm{g} \mathrm{CF} \mathrm{ml}{ }^{-1}$ increased katE expression 1.5-fold when cells grew on glucose, 1.2-fold if growth was on succinate and had no significant effect during growth on acetate (Fig. 6S). Thus, regardless of the substrate used, we did not observe an increase in the expression of antioxidant genes katG and sodA when cells were treated with ciprofloxacin. The increase in $k a t E:: / a c Z$ expression under these conditions was the result of the inhibitory effect of the antibiotic on the growth rate of bacteria.

Consistent with previous data, ciprofloxacin treatment caused an immediate activation of the SOS response (Theodore et al. 2013). Regardless of the substrate used, the increase in sulA::/acZ expression was more pronounced with a lower antibiotic dose (Fig. 5f). Perhaps the lower level of sulA induction with $3 \mu \mathrm{g} \mathrm{CF} \mathrm{ml}{ }^{-1}$ (3 times) compared to $0.3 \mu \mathrm{g} \mathrm{CF} \mathrm{ml}^{-1}$ (10 times) was associated with a sharper inhibition of transcription and translation at a high concentration of the antibiotic.

Effect of $o m p F$, tolC, rpoS, and recA mutations on ciprofloxacin lethality

Among all tested mutations, only mutations in the recA and ompF genes could significantly affect the lethal activity of ciprofloxacin, as follows from the analysis of killing curves (Fig. 6). The effect of ompF deficiency strongly depended on the concentration of ciprofloxacin. At $0.3 \mu \mathrm{g} \mathrm{CF} \mathrm{ml}^{-1}$, its bactericidal activity decreased by 2 times in cells growing on glucose or succinate (Fig. 6a, b), while at $3 \mu \mathrm{g} \mathrm{CF} \mathrm{ml}^{-1}$, it increased 9,3 , and 2 times during growth on glucose, succinate, and acetate, respectively, compared to the parental strain (Fig. 6d, e, f). RecA deficiency reduced the number of CFUs by 2-4 orders of magnitude compared to the parental strain, depending on the concentration of ciprofloxacin and the substrate used. The absence of RpoS only slightly (1.7 times) increased the lethal activity of ciprofloxacin when cells were grown on succinate at both antibiotic concentrations or on glucose at $0.3 \mu \mathrm{g} \mathrm{CF} \mathrm{ml} l^{-1}$ (Fig. 6a, b, e). The tolC mutant showed the same tolerance to ciprofloxacin as the parent. 
The bactericidal activity of quinolones, including ciprofloxacin, is biphasic: the lethality of the drugs increases to a concentration known as the optimal bactericidal concentration (OBC), after which the bactericidal activity then declines (Lewin et al. 1991). In wild type E. coli, the OBC is about $0.3 \mu \mathrm{g} \mathrm{CF} \mathrm{ml}^{-1}$. Accordingly, $0.3 \mu \mathrm{g} \mathrm{CF} \mathrm{ml}^{-1}$ showed a higher bactericidal activity (up to one order of magnitude) than 3 $\mu \mathrm{g} \mathrm{CF} \mathrm{ml}^{-1}$ during the growth of wild-type cells and rpoS and tolC mutants on all tested substrates. In contrast, the dose $3 \mu \mathrm{g} \mathrm{CF} \mathrm{ml}{ }^{-1}$ was more lethal for the recA mutant, regardless of the substrate used. Significant changes in the bactericidal activity of various concentrations of ciprofloxacin were also observed for the ompF mutant. Paradoxically, ompF deficiency increased tolerance to $0.3 \mu \mathrm{g} \mathrm{CF} \mathrm{ml}^{-1}$, but enhanced sensitivity to $3 \mu \mathrm{g} \mathrm{CF} \mathrm{ml}{ }^{-1}$. This may be due to a shift in the OBC for this mutant towards a higher dose of ciprofloxacin compared to the parental strain due to a decrease in the entry of the antibiotic into the cells. In the ompF mutant, the dose of $3 \mu \mathrm{g} \mathrm{CF} \mathrm{ml}^{-1}$ corresponded to the OBC, causing a maximum decrease in CFU; a further increase in the concentration to $10 \mu \mathrm{g} \mathrm{CF} \mathrm{ml}^{-1}$ was accompanied by a decrease in the lethality of the antibiotic (not shown).

Depending on the substrate used, the bactericidal activity of the antibiotic decreased in the sequence: glucose, succinate, acetate, regardless of the E. colistrain and the concentration of ciprofloxacin (Fig. 6). Earlier, we showed for a wild-type strain that there is an inverse correlation between logCFU ml-1 and the specific growth rate of bacteria growing on different energy sources (Smirnova and Oktyabrsky 2018). Our current work has revealed the existence of such a relationship for all studied mutants (Fig. 7). The degree of shift of the graphical dependence of logCFU ml-1 on the specific growth rate along the ordinate in the mutant relative to the wild-type strain reflects the contribution of the corresponding gene to the tolerance to ciprofloxacin. All strains showed the highest tolerance when growing on acetate, which provides the lowest growth rate. The protein synthesis inhibitor chloramphenicol reduced the growth rate to $0.1 \mathrm{~h}^{-1}$ within $60 \mathrm{~min}$ after its addition and caused an increase in ciprofloxacin tolerance similar to that of cells growing on acetate (Fig. 7S). These data confirm that a low growth rate leads to high tolerance, regardless of the reasons that lead to slower growth.

Oxidative stress is thought to be involved in the lethal effects of ciprofloxacin (Hong et al. 2020). However, the absence of RpoS, which controls the induction of $\mathrm{H}_{2} \mathrm{O}_{2}$ scavengers KatG and KatE and the ferrous sequestering protein Dps (Navarro Llorens et al. 2010), only slightly affected the bactericidal activity of this antibiotic (Fig. 6). To test the role of RpoS in protection against oxidative stress under our conditions, we studied the bactericidal activity of $\mathrm{H}_{2} \mathrm{O}_{2}$ in $\mathrm{E}$. coli cells growing at different growth rates. Treatment of cells growing on glucose with $10 \mathrm{mM} \mathrm{H}_{2} \mathrm{O}_{2}$ completely suppressed the growth of both the parental strain and the rpoS mutant, while when cells were cultured on acetate or succinate, gradual growth recovery was observed (Fig. 8Sa, b). Accordingly, this dose of $\mathrm{H}_{2} \mathrm{O}_{2}$ did not kill bacteria growing on succinate and acetate, but showed significant lethality when growing on glucose (Fig. 8Sc). Under these conditions, the rpoS mutant was 3 orders of magnitude more sensitive to $\mathrm{H}_{2} \mathrm{O}_{2}$ than the parent. Prevention of the lethal effect of $\mathrm{H}_{2} \mathrm{O}_{2}$ in slowly growing cells was not the result of induction of the RpoS regulon, as this was observed in both the parental strain and the rpoS mutant. 
We also tested the involvement of oxidative stress in killing E. coli during stress recovery after plating ciprofloxacin-treated cells on LB agar without antibiotic. The presence of catalase in LB agar did not affect the $\mathrm{CFU} \mathrm{m}{ }^{-1}$ in the wild-type strain treated with $0.3 \mu \mathrm{g} \mathrm{CF} \mathrm{ml}^{-1}$ (Fig. 8). However, in line with previous data (Hong et al. 2020), the addition of DMSO to LB agar increased logCFU ml-1 by an order of magnitude. It is known that DMSO traps hydroxyl radicals; therefore, it is possible that oxidative stress is involved in the killing of this part of cells. The procedure for determining the colony forming ability (washing, serial dilutions, and inoculation on the agar surface) involves a change in the composition of the medium, temperature and oxygen concentration and itself represents a series of stresses for the cells. Apparently, defense mechanisms in wild-type cells make it possible to avoid the damaging effect of these stresses. In particular, the addition of catalase and DMSO to agar has no effect on the change in logCFU $\mathrm{ml}^{-1}$ in the control culture (Fig. 8a). In contrast, the plating efficiency of the oxyR mutant was increased by two orders of magnitude with the addition of catalase and by one order of magnitude when the LB agar contained DMSO (Fig. 8b, control curves). These data indicate that the plating bacteria itself induces oxidative stress if the antioxidant system is compromised. In the oxy $R$ mutant, the CFU ml${ }^{-1}$ decreased by 5 times when cells after treatment with ciprofloxacin were plated on LB agar without additives, and by 10 and 100 times when catalase or DMSO was added (Fig. 8b). That is, the killing activity of ciprofloxacin even increased in parallel with an increase in plating efficiency of the oxy $R$ mutant in the presence of catalase and DMSO. It is likely that oxidative stress can lead to additional DNA damage during plating of cells on agar without antibiotic, which complicates the repair of double-stranded DNA breaks formed when the DNA gyrase-ciprofloxacin complex is detached from the DNA. At the same time, in contrast to catalase, the presence of DMSO in the LB medium significantly slowed down the growth of bacteria, especially in the first two hours of cultivation (Fig. 9S). Therefore, it is possible that the protective effect of DMSO in the wild-type strain is associated not only with the direct uptake of hydroxyl radicals, but with an increase in the efficiency of successful repair of DNA damaged by ciprofloxacin in slower growing cells.

\section{Discussion}

Numerous studies indicate that antibiotic exposure to bacterial cells induces a stress response that includes many metabolic and transcriptional alterations that occur after antibiotics interact with their targets (Belenky et al. 2015; Yang et al. 2017). The role of these metabolic changes in antibiotic lethality, especially the involvement of ROS in antibiotic-mediated killing, has become the subject of much debate (Imlay 2015; Van Acker and Coenye 2017). In this work, we evaluated the effect of ciprofloxacin on the physiological parameters of E. coli cells depending on the growth rate of bacteria. We found that the degree and even direction of changes in substrate and oxygen consumption strongly depended on the gradient between the values of the specific growth rate before and after the addition of the antibiotic, that is, on how much growth was inhibited. The degree of growth inhibition increased with an increase in the growth rate of unstressed bacteria and with an increase in the concentration of ciprofloxacin added and penetrated into cells. The slower the cells grew before the antibiotic was added, that is, the fewer targets they had, the weaker the growth inhibition caused by the antibiotic was. More than half of ciprofloxacin 
entered fast-growing cells via $O \mathrm{mpF}$, and its absence in the $\mathrm{ompF}$ mutant resulted in a significant delay in growth inhibition when glucose or succinate was used as a substrate. Substrate consumption, respiration rate, $\mathrm{NAD}^{+} / \mathrm{NADH}$ ratio, and ATP level during treatment of bacteria with ciprofloxacin changed in full accordance with the effect of the antibiotic on the growth rate. This was especially pronounced in the first phase of antibiotic action (the first $60 \mathrm{~min}$ ).

In accordance with previous data (Belenky et al., 2015; Smirnova et al. 2017), increased GSH biosynthesis was observed at this phase of antibiotic exposure. A similar increase in the intracellular GSH level occurred when E. coli cells were treated with chloramphenicol and valine, which suppressed protein synthesis (Smirnova et al. 2019), as well as when glucose was depleted in a growing E. coli culture (Tyulenev et al. 2018). In all cases, including exposure to ciprofloxacin, an increase in the level of intracellular glutathione was a consequence of a temporary increase in the level of cysteine during a sharp inhibition of protein synthesis. Under these conditions, GSH serves as a buffer for cysteine and is involved in maintaining its intracellular homeostasis. From this point of view, it is clear why the amplitude of the increase in GSH in response to ciprofloxacin is the higher, the higher the previous growth rate and the concentration of the antibiotic. Other ways to maintain cysteine homeostasis, in addition to inhibiting its synthesis at the transcriptional and enzymatic levels, are its degradation with the formation of hydrogen sulfide and the release of free cysteine from cells (Smirnova et al. 2019). Here we have shown that the release of $\mathrm{H}_{2} \mathrm{~S}$ during the treatment of cells with ciprofloxacin is catalyzed by the cysteine synthase CysM and occurs only when a high dose of antibiotic is added to a culture growing at a high rate. An increase in the level of intracellular cysteine is dangerous for the cell, since cysteine is able to reduce iron, promoting the Fenton reaction with the formation of toxic hydroxyl radicals (Park and Imlay 2003). In addition, hydrogen sulfide has been shown to be able to protect bacteria growing on LB medium against bactericidal antibiotics (Shatalin et al. 2011). However, upon exposure to ciprofloxacin under our conditions, the deletion of the $c y s M$ gene did not affect either the growth rate or the number of CFU. Similarly, the absence of glutathione in the $g s h A$ mutant only slightly increased the sensitivity of $E$. colito ciprofloxacin (Smirnova et al. 2017). Moreover, the disturbance of cysteine homeostasis in mutants significantly increased the death of bacteria under oxidative stress only when high concentration of $\mathrm{H}_{2} \mathrm{O}_{2}$ (10 mM) was added (Smirnova et al. 2019). Thus, our data show that the temporary disruption of cysteine homeostasis upon treatment with ciprofloxacin of cells growing on a minimal medium does not significantly affect its bactericidal activity. It should be noted, however, that in media containing cysteine or cystine (minimal medium supplemented with casamino acids or LB medium), the role of desulfidases in maintaining cysteine homeostasis may be more significant than in minimal medium with sulfate. Therefore, the effect of a deficiency in cysteine-degrading enzymes on the susceptibility of bacteria to stress, including antibiotic stress, may depend on the culture conditions.

Surprisingly, the deletion of the recA gene causes dramatic changes in glutathione levels inside and outside the cell. We previously observed a similar inversion of GSH levels, when the bulk of the synthesized glutathione is released into the medium, in the phoR mutant with constitutive expression of phosphate regulon (Smirnova et al. 2012). However, we did not find induction of the Pho regulon in the 
recA mutant in a medium containing phosphate (our unpublished result). Disruption of the transmembrane distribution of glutathione in the recA mutant was accompanied by the absence of an increase in $\mathrm{H}_{2} \mathrm{~S}$ production upon treatment with ciprofloxacin. Further studies are needed to clarify the relationship between RecA and transmembrane glutathione fluxes and the possible involvement of GSH in the regulation of RecA, which contains thiol groups, whose mutations can affect its activity (Weisemann and Weinstock 1988).

We did not observe an increase in the expression of the katG and sodA genes under the action of ciprofloxacin on $E$. coli in all the studied situations. Although slow growth was accompanied by an increase in the expression of the $k a t G$ and $k a t E$ genes under the control of RpoS, removal of this regulator had little effect on ciprofloxacin tolerance. Taken together with our previous results, which showed a decrease in superoxide and hydrogen peroxide production when ciprofloxacin treated cells growing on glucose (Smirnova et al. 2017), these data indicate a weak contribution of oxidative stress to the antibacterial effect of ciprofloxacin under our conditions. It should be noted that even strong peroxide stress $\left(10 \mathrm{mM} \mathrm{H}_{2} \mathrm{O}_{2}\right)$ in slowly growing cells did not kill bacteria regardless of the presence or absence of RpoS. Apparently, a decrease in the number of targets for oxidative damage and their more efficient repair during slow growth were more important for survival than the induction of RpoS-controlled defense systems.

Changes in the physiological parameters of cultures (specific growth rate, $\mathrm{pH}, \mathrm{dO}_{2}, \mathrm{ATP}, \Delta \psi$ ) in the first phase of exposure to ciprofloxacin were similar in the wild-type strain and recA mutant, that is, they did not depend on the induction of the SOS response. The onset and duration of the second, SOS-dependent phase varied depending on the concentration of the antibiotic and the substrate on which the cells grew. In all cases, during this phase, $\mu$ drops to 0 and below, further inhibition of respiration occurs, $\Delta \psi$ drops sharply, the level of ATP stabilises or decreases, and glutathione is released from the cells into the medium. The extent of the observed changes decreased in slowly growing bacteria and was minimal in the medium with acetate. The described events, which may be considered as hallmarks of programmed cell death, an extreme SOS response (Dwyer et al. 2012; Erental et al. 2014), were absent in the recA mutant. This mechanism operates at a later stage of the SOS response when DNA damage cannot be repaired and is likely the result of the induction of SOS-dependent toxins TisB and DinQ, which can form pores in the inner membrane of E. coli (Dörr et al. 2010; Brantl and Jahn 2015). The complete cessation of metabolism at this phase may facilitate the transition of some cells to the dormant state, which contributes to the formation of persisters.

The most commonly used test for bactericidal activity of antibiotics is to determine the CFU after plating dilutions of antibiotic-treated cultures onto antibiotic-free agar plates to plot killing curves. However, the shape of the killing curves obtained by us for wild-type bacteria and mutants upon exposure to ciprofloxacin does not coincide with the shape of the curves reflecting the effect of the antibiotic on growth, respiration, $\mathrm{pH}, \Delta \psi$, and ATP level. Analysis of physiological parameters, including real-time monitoring data, shows that most cells in liquid culture remain alive during the first hour of exposure to ciprofloxacin. At the same time, according to CFU data, rapid cell death occurs precisely during the first 
hour of antibiotic exposure. Moreover, the recA mutant, which does not show significant differences from the parental strain in terms of the growth rate change, demonstrates a three orders of magnitude decrease in the logCFU ml${ }^{-1}$ already during the first $30 \mathrm{~min}$ of ciprofloxacin exposure. Such a discrepancy between changes in the physiological parameters of bacteria in liquid culture and the CFU on the plates indicates that most of the bacteria lose their viability after removal of the antibiotic as a result of the inability to repair DNA damage and recover growth. The quinolones inhibit DNA supercoiling and relaxation by binding to both gyrase and DNA and stabilising the gyrase-DNA-cleaved complex. This topoisomerase-DNA-quinolone complex transforms the enzyme into a poisonous protein that blocks the replication and transcription machinery, potentially causing lethal double-strand breaks after the gyrase removing from DNA (Bush et al. 2020). The higher the activity of antibiotic targets, the greater the likelihood of their damage, which explains the inverse linear dependence of logCFU ml-1 on the growth rate for all studied strains. The quinolone-induced DNA damage can be repaired by SOS-regulated genes; therefore $E$. coli tolerance to quinolones depends on the SOS response (Theodore et al. 2013). The SOS response is induced immediately after the addition of ciprofloxacin to the bacterial culture. The second SOS induction occurs in persister cells during the recovery phase (Goormaghtigh and Van Melderen 2019). In addition to repair of double-strand breaks, ciprofloxacin tolerance depends on the repair of collapsed replication forks and stalled transcription complexes (Theodore et al. 2013). The inability to repair DNA damage at the stage of growth recovery in antibiotic-free medium apparently explains the sharp drop in CFU in the recA mutant during the first $30 \mathrm{~min}$ of exposure to ciprofloxacin. Some of the enzymes involved in DNA repair are under the LexA-independent control of RpoS (Maslowska et al. 2019). However, unlike recA, the rpoS mutation did not cause a significant shift in the plot of logCFU ml-1 versus growth rate, which indicates its minor role in ciprofloxacin tolerance.

It has recently been reported that ROS continue to accumulate on drug-free agar after quinolone removal and are the dominant factor in all modes of quinolone-mediated lethality (Hong et al. 2020). Our study has shown that the plating of bacteria itself can trigger oxidative stress in the $\operatorname{oxy} R$ mutant when the antioxidant system is corrupted. It can be assumed that DNA damage caused by ciprofloxacin disrupts the normal induction of antioxidant systems, which contributes to the appearance of additional damage associated with oxidative stress during bacterial plating, and complicates DNA repair. However, the addition of catalase did not affect the number of CFUs after treatment of wild-type cells with ciprofloxacin. DMSO, in addition to trapping hydroxyl radicals, can inhibit bacterial growth, and its protective effect may at least in part be caused by growth delay, as a similar effect was observed when M9 agar without DMSO was used instead of LB agar with DMSO. It has been reported that (p)ppGpp, which is elevated in slowly growing cells, can facilitate DNA repair by promoting UvrD-mediated RNAP backtracking (Kamarthapu et al. 2016), and is also required to promote new origin formation (Myka et al. 2019). Therefore, more research is needed to elucidate the role of ROS in the lethality of ciprofloxacin during the recovery of bacterial growth on drug-free plates.

It was previously shown that a decrease in bacterial growth rate can increase persistence in the absence of (p)ppGpp (Chowdhury et al. 2016). In this study, we showed that an inverse linear relationship between 
$\log \mathrm{CFU} \mathrm{ml}{ }^{-1}$ and specific growth rate is characteristic for all studied strains, regardless of the mutation used, which is explained by the direct dependence of the number of active targets for antibiotics on the specific growth rate. Mutations shift the graph of this relationship relative to the parental strain in accordance with their significance for preventing and repairing DNA damage and, as a consequence, for tolerance to ciprofloxacin. The crucial role of the SOS system is confirmed by dramatic shift down of this plot in the recA mutant.

\section{Declarations}

Funding This work was carried out in accordance with state assignment AAAA-A19-119112290009-1 and supported by grants from the Russian Foundation for Basic Research 19-04-00888, the President of the Russian Federation for young scientists MK-420.2020.4 and Norpexal Foundation.

Conflict of interest All authors declare that they have no conflict of interest.

Data availability All data generated during this study are included in this published article and its supplementary information files.

Author contributions ONO developed the concept and design of the study; GVS carried out experiments, analysed data, and wrote the manuscript; NGM and AVT carried out experiments and analysed the experimental results. All authors read and approved the final version of the manuscript.

Ethical approval This article does not contain any studies with human participants or animals performed by any of the authors.

Consent statement All authors agreed to participate in this paper. All authors agreed for publication of this paper in "Antonie van Leeuwenhoek Journal of Microbiology", if accepted.

\section{References}

1. Amato SM, Orman MA, Brynildsen MP (2013) Metabolic control of persister formation in Escherichia coli. Mol Cell 50:475-487. https://doi.org/10.1016/j.molcel.2013.04.002

2. Baba T, Ara T, Hasegawa M, Takai Y, Okumura Y, Baba M et al (2006) Construction of Escherichia coli $\mathrm{K}-12$ in-frame, single-gene knockout mutants: the Keio collection. Mol Syst Biol 2:1-11. https://doi.org/10.1038/msb4100050

3. Bailey AM, Webber MA, Piddock LJV (2006) Medium plays a role in determining expression of acrB, marA, and soxS in Escherichia coli. Antimicrob Agents Chemother 50:1071-1074. https://doi.org/10.1128/AAC.50.3.1071-1074.2006

4. Belenky P, Ye JD, Porter CBM, Cohen NR, Lobritz MA, Ferrante T, Jain S, Korry BJ, Schwarz EG, Walker GC, Collins JJ (2015) Bactericidal antibiotics induce toxic metabolic perturbations that lead to cellular damage. Cell Rep 13:968-980. https://doi.org/10.1016/j.celrep.2015.09.059 
5. Brantl S, Jahn N (2015) sRNAs in bacterial type I and type III toxin-antitoxin systems. FEMS Microbiol 39:413-442. https://doi.org/10.1093/femsre/fuv003

6. Bush NG, Diez-Santos I, Abbott LR, Maxwell A (2020) Quinolones: mechanism, lethality and their contributions to antibiotic resistance. Molecules 25:5662. https://doi.org/10.3390/molecules25235662

7. Carlioz A, Touati $D$ (1986) Isolation of superoxide dismutase mutants in Escherichia coli: is superoxide dismutase necessary for aerobic life? EMBO 5:623-630

8. Chowdhury N, Kwan BW, Wood TK (2016) Persistence increases in the absence of the alarmone guanosine tetraphosphate by reducing cell growth. Sci Rep 6:20519. https://doi.org/10.1038/srep20519

9. Compan I, Touati D (1993) Interaction of six global transcriptional regulators in expression of manganese superoxide dismutases in Escherichia coli K-12. J Bacteriol 175:1687-1696. https://doi.org/10.1128/jb.175.6.1687-1696.1993

10. Dörr T, Vulic M, Lewis K (2010) Ciprofloxacin causes persister formation by inducing the TisB toxin in Escherichia coli. PLoS Biol 8:e1000317. https://doi.org/10.1371/journal.pbio.1000317

11. Durfee T, Hansen AM, Zhi H, Blattner FR, Ding JJ (2008) Transcription profiling of the stringent response in Escherichia coli. J Bacteriol 190:1084-1096. https://doi.org/10.1128/JB.01092-07

12. Dwyer DJ, Camacho DM, Kohanski MA, Callura JM, Collins JJ (2012) Antibiotic-induced bacterial cell death exhibits physiological and biochemical hallmarks of apoptosis. Mol Cell 46:561-572. https://doi.org/10.1016/j.molcel.2012.04.027

13. Eng RHK, Padberg FT, Smith SM, Tan EN, Cherubin CE (1991) Bactericidal effects of antibiotics on slowly growing and nongrowing bacteria. Antimicrob Agents Chemother 35:1824-1828. https://doi.org/10.1128/aac.35.9.1824

14. Erental A, Kalderon Z, Saada A, Smith Y, Engelberg-Kulka H (2014) Apoptosis-like death, an extreme SOS response in Escherichia coli. mBio 5(4):e01426-e01414. https://doi.org/10.1128/mBio.0142614

15. Fung DKC, Chan EWC, Chin ML, Chan RCY (2010) Delineation of a bacterial starvation stress response network which can mediate antibiotic tolerance development. Antimicrob Agents Chemother 54:1082-1093. https://doi.org/10.1128/AAC.01218-09

16. Goormaghtigh F, Van Melderen L (2019) Single-cell imaging and characterization of Escherichia coli persister cells to ofloxacin in exponential cultures. Sci Adv 5:eaav9462. https://doi.org/10.1126/sciadv.aav9462

17. Goswami M, Subramanian M, Kumar R, Jass J, Jawali N (2016) Involvement of antibiotic efflux machinery in glutathione-mediated decreased ciprofloxacin activity in Escherichia coli. Antimicrob Agents Chemother 60:4369 - 4374. https://doi.org/10.1128/AAC.00414-16

18. Greulich P, Scott M, Evans MR, Allen RJ (2015) Growth-dependent bacterial susceptibility to ribosome-targeting antibiotics. Mol Syst Biol 11:796. https://doi.org/10.15252/msb.20145949 
19. Hansen S, Lewis K, Vulic M (2008) Role of global regulators and nucleotide metabolism in antibiotic tolerance in Escherichia coli. Antimicrob Agents Chemother 52:2718-2726.

https://doi.org/10.1128/AAC.00144-08

20. Haugan MS, Lwbner-Olesen A, Frimodt-Mwller N (2018) Comparative activity of ceftriaxone, ciprofloxacin, and gentamicin as a function of bacterial growth rate probed by Escherichia coli chromosome replication in the mouse peritonitis model. Antimicrob Agents Chemother 63:e02133e02118. https://doi.org/10.1128/AAC.02133-18

21. Hengge R (2008) The two-component network and the general stress sigma factor RpoS $\left(\sigma^{S}\right)$ in Escherichia coli. Adv Exp Med Biol 631:40-53. https://doi.org/10.1007/978-0-387-78885-2_4

22. Hirai K, Aoyama H, Irikura T, lyobe S, Mitsuhashi S (1986) Differences in susceptibility to quinolones of outer membrane mutants of Salmonella typhimurium and Escherichia coli. Antimicrob Agents Chemother 29:535-538. https://doi.org/10.1128/aac.29.3.535

23. Hong Y, Li Q, Gao Q, Xie J, Huang H, Drlica K, Zhao X (2020) Reactive oxygen species play a dominant role in all pathways of rapid quinolone-mediated killing. J Antimicrob Chemother 75:576585. https://doi.org/10.1093/jac/dkz485

24. Ihssen J, Egli T (2004) Specific growth rate and not cell density controls the general stress response in Escherichia coli. Microbiology 150:1637-1648. https://doi.org/10.1099/mic.0.26849-0

25. Imlay JA (2013) The molecular mechanisms and physiological consequences of oxidative stress: lessons from a model bacterium. Nature Rev Microbiol 11:443-454.

https://doi.org/10.1038/nrmicro3032

26. Imlay JA (2015) Diagnosing oxidative stress in bacteria: not as easy as you might think. Curr Opin Microbiol 24:124-131. https://doi.org/10.1016/j.mib.2015.01.004

27. Ivanova A, Miller C, Glinsky G, Eisenstark A (1994) Role of the rpoS(katF) in oxyR independent regulation of hydroperoxidase I in Escherichia coli. Mol Microbiol 12:571-578.

https://doi.org/10.1111/j.1365-2958.1994.tb01043.x

28. Kaldalu N, Hauryliuk V, Turnbull KJ, La Mensa A, Putrinš M, Tenson T (2020) In vitro studies of persister cells. Microbiol Mol Biol Rev 84:e00070-e00020. https://doi.org/10.1128/MMBR.00070-20

29. Kamarthapu V, Epshtein V, Benjamin B, Proshkin S, Mironov A, Cashel M, Nudler E (2016) ppGpp couples transcription to DNA repair in E. coli. Science 352:993-996. https://doi.org/10.1126/science.aad6945

30. Korshunov S, Imlay JA (2006) Detection and quantification of superoxide formed within the periplasm of Escherichia coli. J Bacteriol 188:6326-6334. https://doi.org/10.1128/JB.00554-06

31. Lee AJ, Wang S, Meredith HR, Zhuang B, Dai Z, You L (2018) Robust, linear correlations between growth rates and $\beta$-lactam-mediated lysis rates. Proc Natl Acad Sci U S A 115:4069-4074. https://doi.org/10.1073/pnas.1719504115

32. Leonardo MR, Dailly Y, Clark DP (1996) Role of NAD in regulating the adhE gene in Escherichia coli. J Bacteriol 178:6013-6018. https://doi.org/10.1128/jb.178.20.6013-6018.1996 
33. Lewin CS, Morrissey I, Smith JT (1991) The mode of action of quinolones: the paradox in activity of low and high concentrations and activity in the anaerobic environment. Eur $\mathrm{J}$ Clin Microbiol Infect Dis 10:240-248

34. Maslowska KH, Makiela-Dzbenska K, Fijalkowska IJ (2019) The SOS system: a complex and tightly regulated response to DNA damage. Environ Mol Mutagen 60:368-384. https://doi.org/10.1002/em.22267

35. Matin A (1991) The molecular basis of carbon-starvation-induced general resistance in Escherichia coli. Mol Microbiol 5:3-10. https://doi.org/10.1111/j.1365-2958.1991.tb01819.x

36. Miller JH (1972) Experiments in molecular genetics, Cold Spring Harbor. Cold Spring Harbor Laboratory Press, New York

37. Mulvey MR, Switala J, Boris A, Loewen PC (1990) Regulation of transcription of katE and katF. Escherichia coli J Bacteriol 172:6713-6720

38. Myka KK, Küsters K, Washburn R, Gottesman ME (2019) DksA-RNA polymerase interactions support new origin formation and DNA repair in Escherichia coli. Mol Microbiol 111:1382-1397. https://doi.org/10.1111/mmi.14227

39. Navarro Llorens JM, Tormo A, Martinez-Garcia E (2010) Stationary phase in gram-negative bacteria. FEMS Microbiol Rev 34:476-495. https://doi.org/10.1111/j.1574-6976.2010.00213.x

40. Nguyen D, Joshi-Datar A, Lepine F, Bauerle E, Olakanmi O, Beer K, McKay G, Siehnel R, Schafhauser J. Wang Y, Britigan BE, Singh PK (2011) Active starvation responses mediate antibiotic tolerance in biofilms and nutrient-limited bacteria. Science 334:982-986. https://doi.org/10.1126/science.1211037

41. Park S, Imlay JA (2003) High levels of intracellular cysteine promote oxidative DNA damage by driving the Fenton reaction. J Bacteriol 185:1942-1950. https://doi.org/10.1128/JB.185.6.19421950.2003

42. Pontes MH, Groisman EA (2019) Slow growth determines nonheritable antibiotic resistance in Salmonella enterica. Sci Signal 12:eaax3938. https://doi.org/10.1126/scisignal.aax3938

43. Pontes MH, Groisman EA (2020) A physiological basis for nonheritable antibiotic resistance. mBio 11:e00817-e00820. https://doi.org/10.1128/mBio.00817-20

44. Potrykus K, Murphy H, Philippe N, Cashel M (2011) ppGpp is the major source of growth rate control. E coli Environ Microbiol 13:563-575. https://doi.org/10.1111/j.1462-2920.2010.02357.x

45. Pu Y, Zhao Z, Li Y, Zou J, Ma Q, Zhao Y, Ke Y, Zhu Y, Chen H, Baker MAB, Ge H, Sun Y, Xie XS, Bai F (2016) Enhanced efflux activity facilitates drug tolerance in dormant bacterial cells. Mol Cell 62:284294. https://doi.org/10.1016/j.molcel.2016.03.035

46. Radzikowski JL, Vedelaar S, Siegel D, Ortega AD, Schmidt A, Heinemann M (2016) Bacterial persistence is an active sigmaS stress response to metabolic flux limitation. Mol Syst Biol 12:882. https://doi.org/10.15252/msb.20166998

47. Rand JD, Danby SG, Greenway DL, England RR (2002) Increased expression of the multidrug efflux genes acrAB occurs during slow growth of Escherichia coli. FEMS Microbiol Lett 207:91-95 
48. Seaver LC, Imlay JA (2001) Alkyl hydroperoxide reductase is the primary scavenger of endogenous hydrogen peroxide in Escherichia coli. J Bacteriol 183:7173-7181. https://doi.org/10.1128/JB.183.24.7173-7181.2001

49. Shatalin $\mathrm{K}$, Shatalina $\mathrm{E}$, Mironov A, Nudler $\mathrm{E}(2011) \mathrm{H}_{2} \mathrm{~S}$ : A universal defense against antibiotics in bacteria. Science 334:986-990. https://doi.org/10.1126/science.1209855

50. Smirnova G, Muzyka N, Oktyabrsky O (2012) Transmembrane glutathione cycling in growing Escherichia coli cells. Microbiol Res 167:166-172. https://doi.org/10.1016/j.micres.2011.05.005

51. Smirnova GV, Muzyka NG, Ushakov VY, Tyulenev AV, Oktyabrsky ON (2015) Extracellular superoxide provokes glutathione efflux from Escherichia coli cells. Res Microbiol 166:609-617. https://doi.org/10.1016/j.resmic.2015.07.007

52. Smirnova GV, Oktyabrsky ON (2018) Relationship between Escherichia coli growth rate and bacterial susceptibility to ciprofloxacin. FEMS Microbiol Lett 365:10.1093/femsle/fnx254. https://doi.org/10.1093/femsle/fnx254

53. Smirnova GV, Tyulenev AV, Bezmaternykh KV, Muzyka NG, Ushakov VY, Oktyabrsky ON (2019) Cysteine homeostasis under inhibition of protein synthesis in Escherichia coli cells. Amino Acids 51:1577-1592. https://doi.org/10.1007/s00726-019-02795-2

54. Smirnova GV, Tyulenev AV, Muzyka NG, Peters MA, Oktyabrsky ON (2017) Ciprofloxacin provokes SOS-dependent changes in respiration and membrane potential and causes alterations in the redox status of Escherichia coli. Res Microbiol 168:64-73. https://doi.org/10.1016/j.resmic.2016.07.008

55. Steinchen W, Bange G (2016) The magic dance of the alarmones ( $p$ )ppGpp. Mol Microbiol 101:531544

56. Sufya N, Allison DG, Gilbert P (2003) Clonal variation in maximum specific growth rate and susceptibility towards antimicrobials. J Appl Microbiol 95:1261-1267. https://doi.org/10.1046/j.1365-2672.2003.02079.x

57. Tao K, Makino K, Yonei S, Nacata A, Shinagawa H (1989) Molecular cloning and nucleotide sequencing of $\operatorname{oxy} R$, the positive regulatory gene of a regulon for an adaptive response to oxidative stress in Escherichia coli: homologies between OxyR protein and a family of bacterial activator proteins. Mol Gen Genet 218:371-376. https://doi.org/10.1007/bf00332397

58. Theodore A, Lewis K, Vulic M (2013) Tolerance of Escherichia coli to fluoroquinolone antibiotics depends on specific components of the SOS response pathway. Genetics 195:1265-1276. https://doi.org/10.1534/genetics.113.152306

59. Tietze $F$ (1969) Enzymic method for quantitative determination of nanogram amounts of total and oxidized glutathione: applications to mammalian blood and other tissues. Anal Biochem 27:502522. https://doi.org/10.1016/0003-2697(69)90064-5

60. Tuomanen E, Cozens R, Tosch W, Zak O, Tomasz A (1986) The rate of killing of Escherichia coli by $\beta$ lactam antibiotics is strictly proportional to the rate of bacterial growth. J Gen Microbiol 132:12971304. https://doi.org/10.1099/00221287-132-5-1297 
61. Tyulenev A, Smirnova G, Muzyka N, Ushakov V, Oktyabrsky O (2018) The role of sulfides in stressinduced changes of Eh in Escherichia coli cultures. Bioelectrochemistry 121:11-17. https://doi.org/10.1016/j.bioelechem.2017.12.012

62. Van Acker H, Coenye T (2017) The role of reactive oxygen species in antibiotic-mediated killing of bacteria. Trends Microbiol 25:456-466. https://doi.org/10.1016/j.tim.2016.12.008

63. Volkert MR, Gately FH, Hajec LI (1989) Expression of DNA damage-inducible genes of Escherichia coli upon treatment with methylating, ethylating and propylating agents. Mutation Res 217:109-115

64. Weisemann JM, Weinstock GM (1988) Mutations at the cysteine codons of the recA gene of Escherichia coli. DNA 7:389-398

65. Wickens HJ, Pinney RJ, Mason DJ, Gant VA (2000) Flow cytometric investigation of filamentation, membrane patency and membrane potential in Escherichia coli following ciprofloxacin exposure. Antimicrob Agents Chemother 44:682-687. https://doi.org/10.1128/AAC.44.3.682-687.2000

66. Yang JH, Bening SC, Collins JJ (2017) Antibiotic efficacy - context matters. Curr Opin Microbiol 39:73-80. http://dx.doi.org/10.1016/j.mib.2017.09.002

\section{Figures}



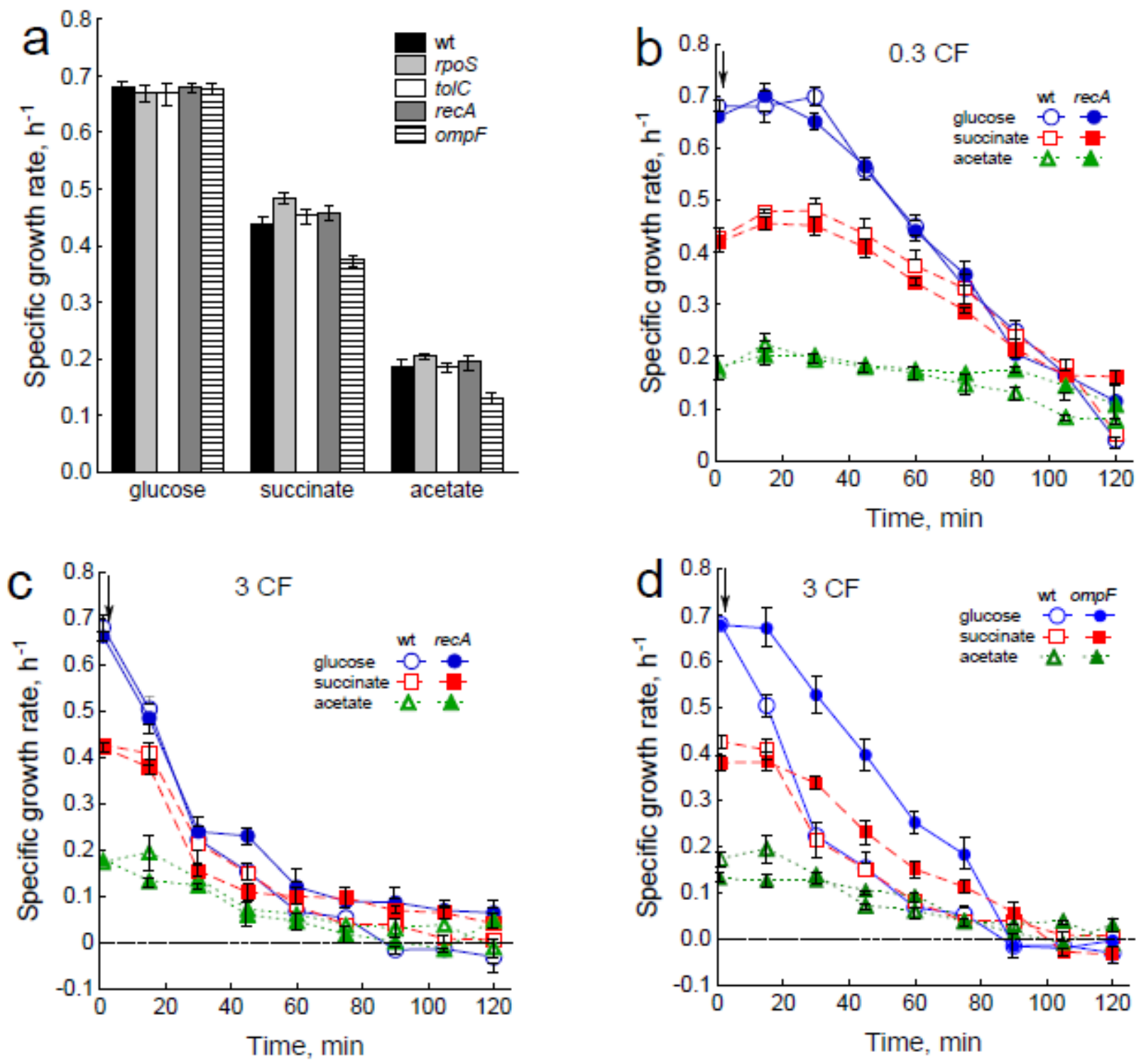

Figure 1

Effect of mutations and energy substrates on E. coli growth rate in the absence (a) and in the presence of $0.3 \mu \mathrm{g} \mathrm{CF} \mathrm{ml-1}$ (b) or $3 \mu \mathrm{g} \mathrm{CF} \mathrm{ml-1} \mathrm{(c,} \mathrm{d).} \mathrm{E.} \mathrm{coli} \mathrm{cells} \mathrm{were} \mathrm{grown} \mathrm{in} \mathrm{M9} \mathrm{minimal} \mathrm{medium} \mathrm{with} \mathrm{glucose,}$ succinate or acetate. Ciprofloxacin was added at OD600 of 0.4 at the time indicated by the arrow. Values are the means and standard error (vertical bars) from at least three independent experiments 

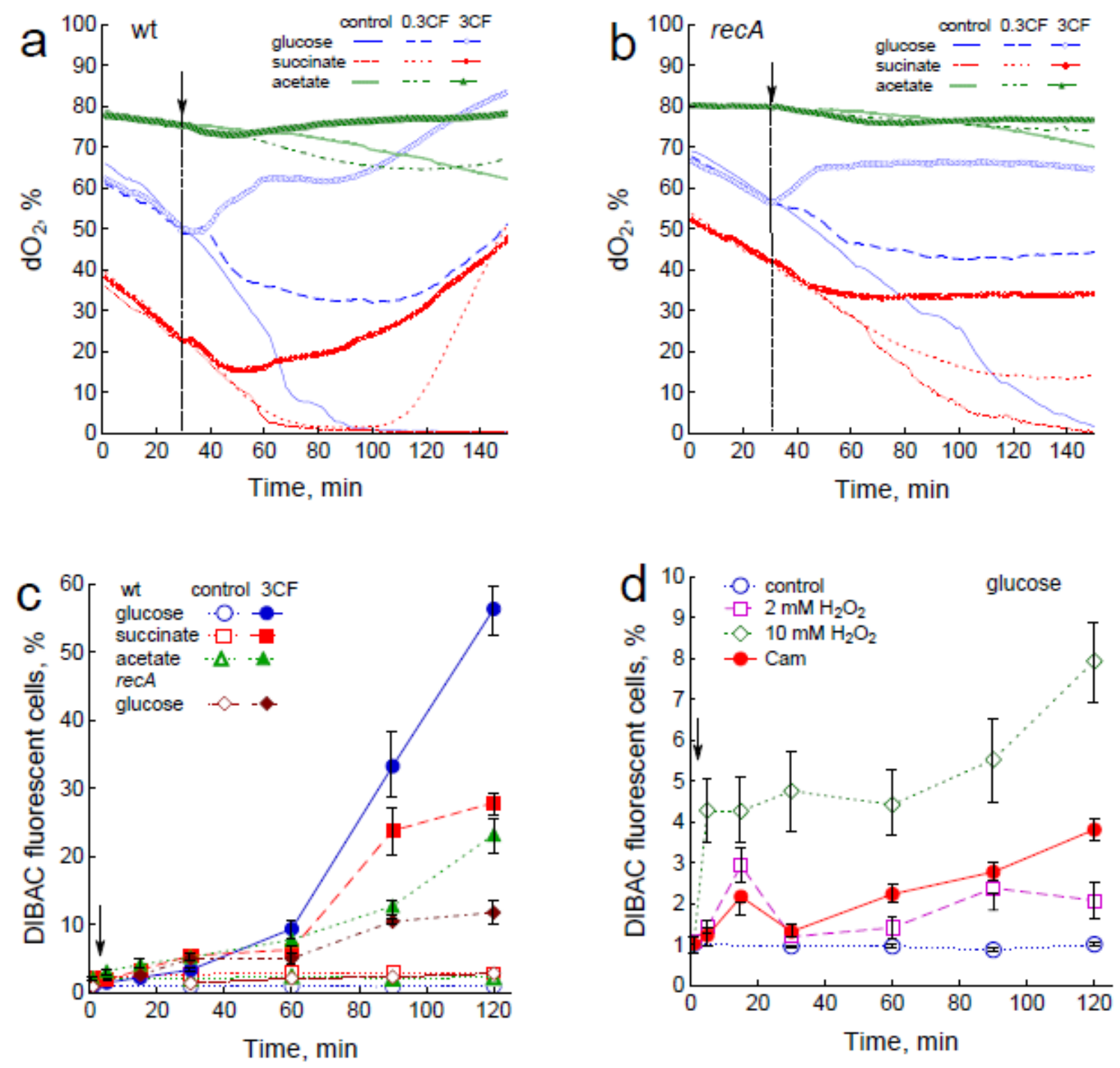

Figure 2

Changes in $\mathrm{dO} 2(\mathrm{a}, \mathrm{b})$ and membrane potential $(c, d)$ after the treatment of E. coli with ciprofloxacin $(a, b$, c) or other drugs (d). E. coli cells were grown in M9 minimal medium with glucose, succinate or acetate. Ciprofloxacin $(0.3 \mu \mathrm{g} \mathrm{ml}-1$ or $3 \mu \mathrm{g} \mathrm{ml}-1)$, chloramphenicol (Cam, $25 \mu \mathrm{g} \mathrm{ml}-1)$ or H2O2 (2 mM or $10 \mathrm{mM}$ ) were added at OD600 of 0.4 at the time indicated by the arrow. Each experiment was repeated at least three times. The data shown are representative for d02 measurements $(a, b)$ or are presented as the means and standard error (vertical bars) for experiments with DiBAC4(3) 

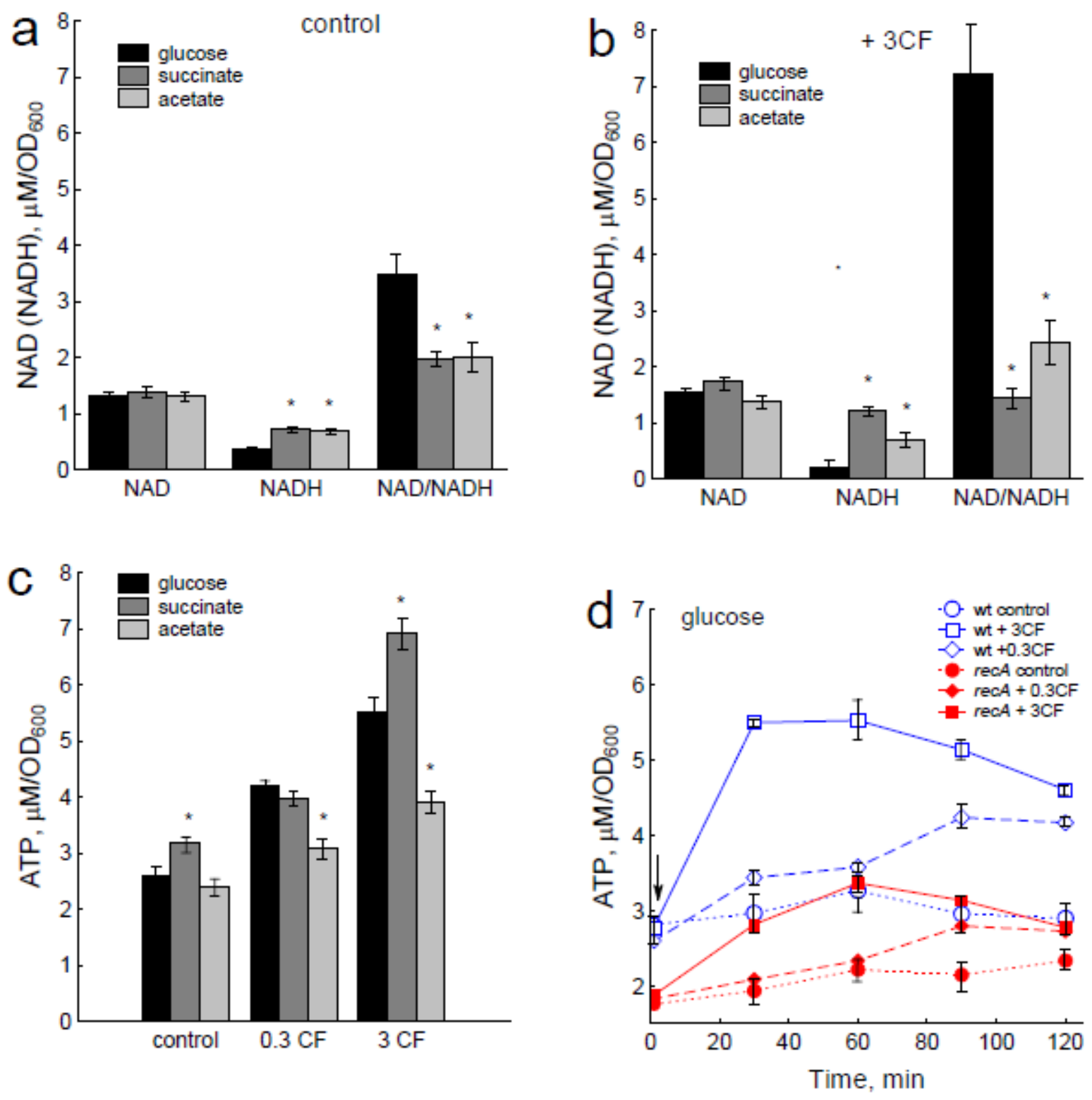

Figure 3

Changes in the pools of NAD-NADH $(a, b)$ and ATP $(c, d)$ in E. coli untreated $(a)$ or treated with ciprofloxacin (b, c, d). E. coli cells were grown in M9 minimal medium with glucose, succinate or acetate. Ciprofloxacin was added at OD600 of 0.4. b - data obtained after 20 min exposure to $3 \mu \mathrm{g} \mathrm{CF} \mathrm{ml} \mathrm{-1.} \mathrm{c} \mathrm{-}$ data obtained after 60 min exposure to ciprofloxacin. Values are the means and standard error (vertical bars) from at least three independent experiments. Statistical differences compared to the cells growing on glucose $(P<0.05)$ are noted with asterisk 

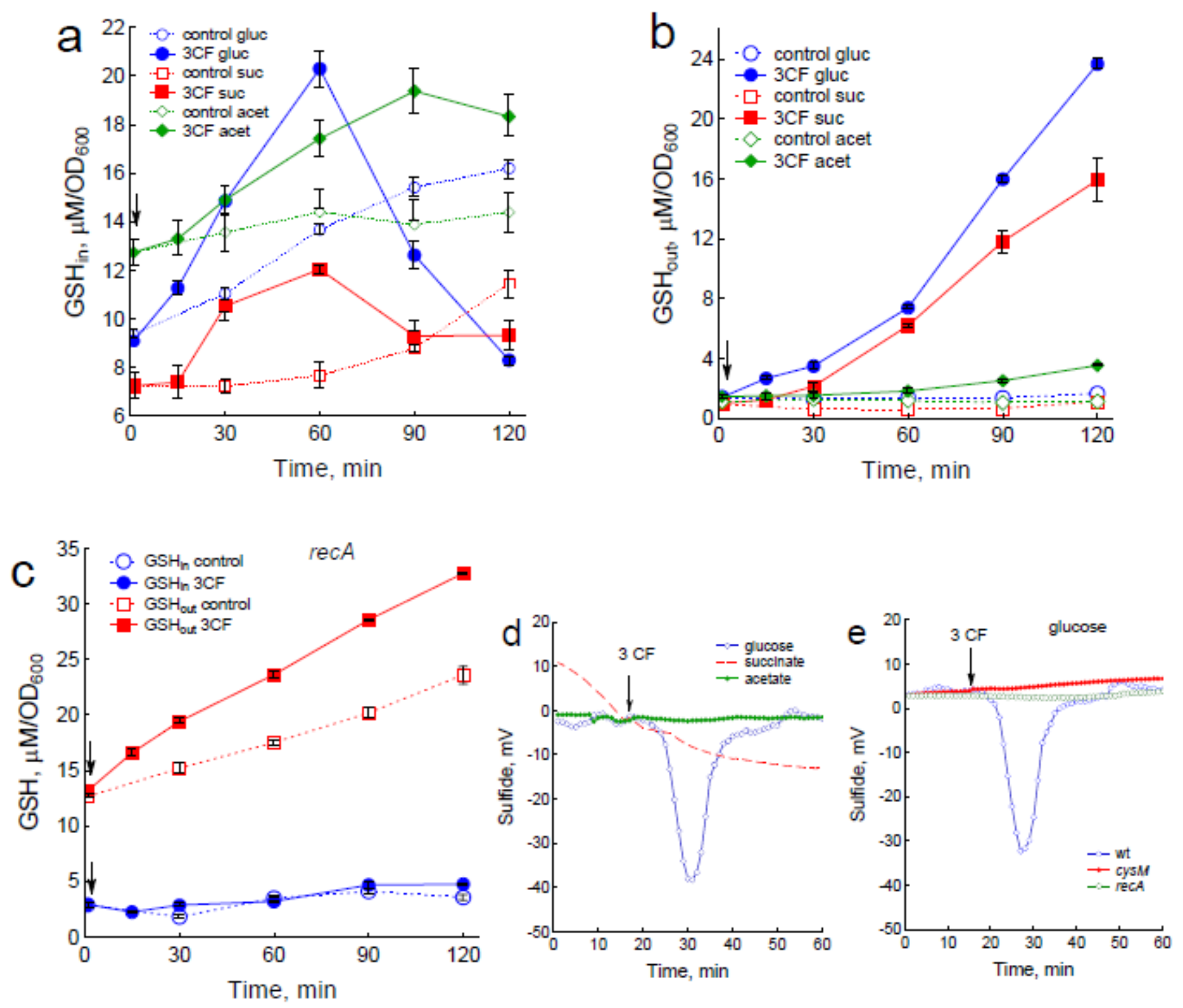

Figure 4

Effect of $3 \mu \mathrm{g} \mathrm{CF} \mathrm{ml}-1$ on intracellular (a) and extracellular (b) levels of glutathione in wt $(a, b)$ and recA (c) cells, as well as on $\mathrm{H} 2 \mathrm{~S}$ production in the wt (d) and recA and cysM mutants (e). E. coli cells were grown in M9 minimal medium with glucose, succinate or acetate. Ciprofloxacin was added at OD600 of 0.4. Values are the means and standard error (vertical bars) from at least three independent experiments $(a, b, c) . d, e-$ the data shown are representative 

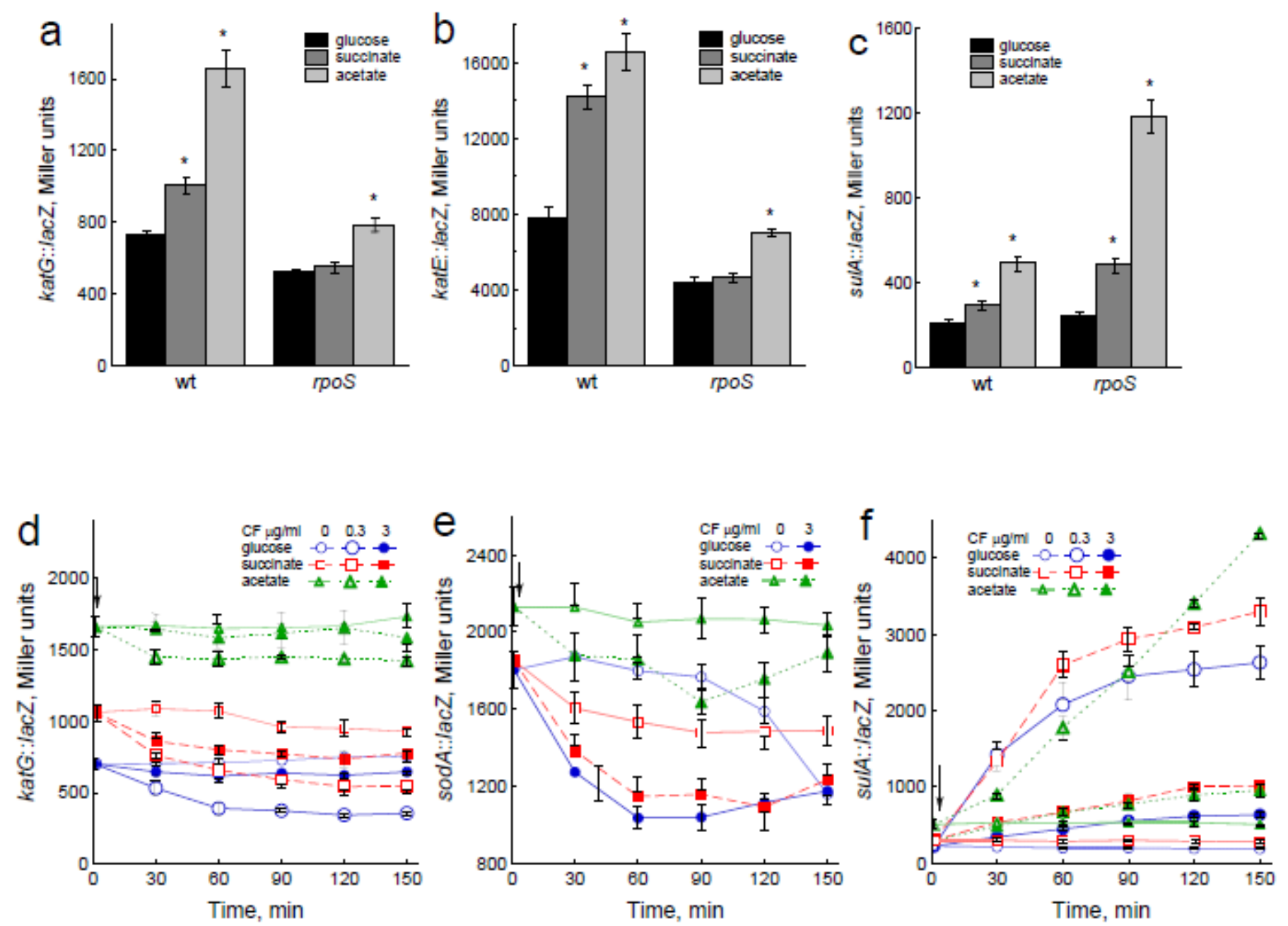

\section{Figure 5}

The expression of the katG (a), katE (b), and sulA (c) genes depended on the growth rate and significantly changed in the rpoS mutant. Exposure to ciprofloxacin decreased the expression of the katG (d) and sodA (e) genes and increased the expression of the sulA gene (f), regardless of the substrate used. E. coli cells were grown in M9 minimal medium with glucose, succinate or acetate. Ciprofloxacin was added at OD600 of 0.4 at the time indicated by the arrow. Values are the means and standard error (vertical bars) from at least three independent experiments. Statistical differences compared to the cells growing on glucose $(P<0.05)$ are noted with asterisk 

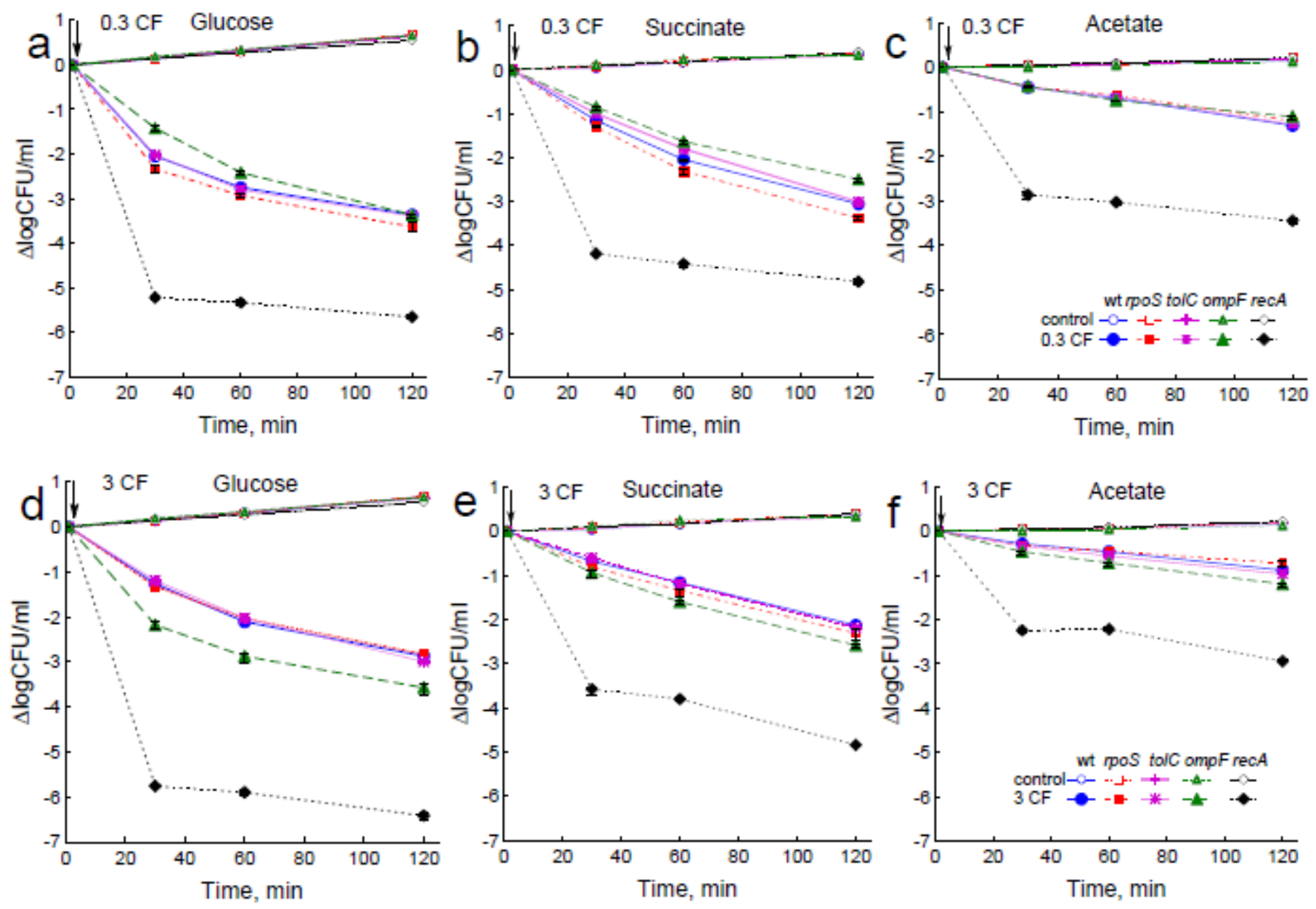

Figure 6

Effect of ompF, tolC, rpoS, and recA mutations on ciprofloxacin lethality at different growth rates. E. coli cells were grown in M9 minimal medium with glucose $(a, d)$, succinate $(b, e)$ or acetate $(c, f) .0 .3 \mu \mathrm{g}$ CF ml-1 (a, b, c) or $3 \mu \mathrm{g} \mathrm{CF} \mathrm{ml-1} \mathrm{(d,} \mathrm{e,} \mathrm{f)} \mathrm{were} \mathrm{added} \mathrm{at} \mathrm{OD600} \mathrm{of} 0.4$ at the time indicated by the arrow. Values are the means and standard error (vertical bars) from at least three independent experiments 

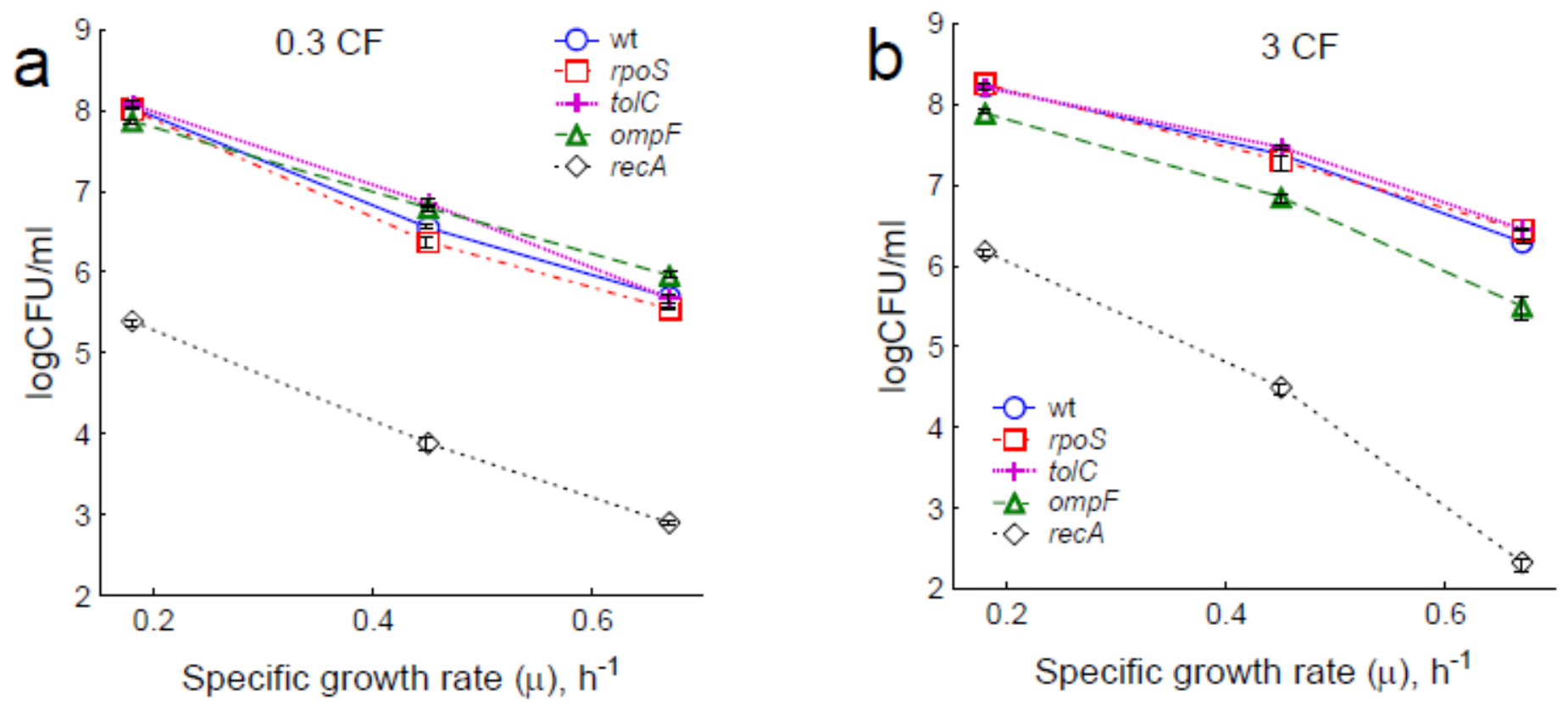

Figure 7

All studied mutants showed an inverse linear relationship between logCFU ml-1 and the specific growth rate. Mutations shifted the plot of this dependence relative to the parental strain according to their significance for ciprofloxacin tolerance. Data are taken from the killing curves (Fig. 6) one hour after antibiotic treatment
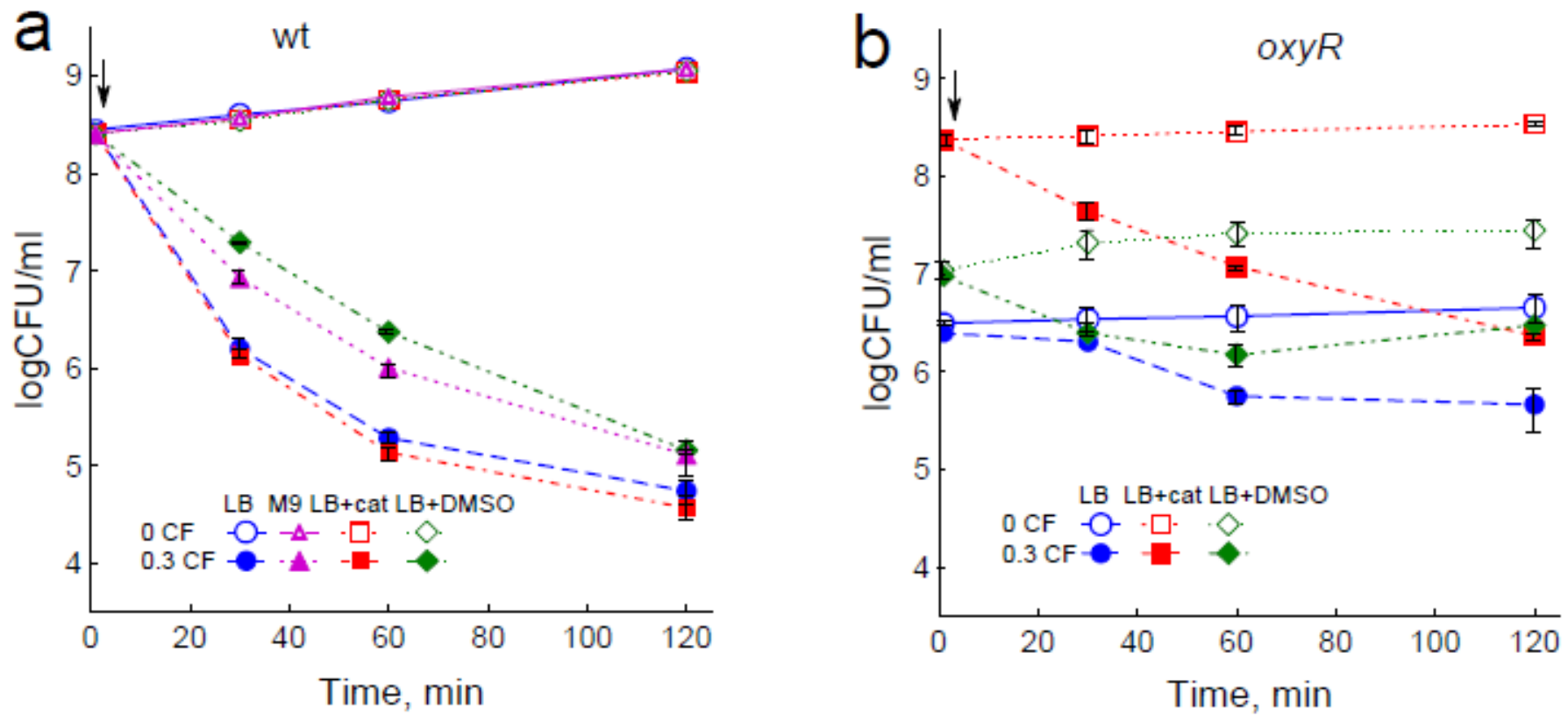

Figure 8

Effect of the addition of catalase or DMSO to LB agar in wild type (a) and oxyR mutant (b). The parental strain and the oxyR mutant were grown in M9 minimal medium with glucose up to OD600 of 0.4, and 
then part of the culture was treated with $0.3 \mu \mathrm{g} \mathrm{CF} \mathrm{ml-1.} \mathrm{Samples} \mathrm{of} \mathrm{untreated} \mathrm{(control)} \mathrm{and} \mathrm{ciprofloxacin}$ treated cells were removed and, after serial dilutions, plated on LB agar without additives or with the addition of catalase (500 U ml-1) or DMSO (5\%). Values are the means and standard error (vertical bars) from at least three independent experiments. The time of $\mathrm{CF}$ addition is indicated by an arrow

\section{Supplementary Files}

This is a list of supplementary files associated with this preprint. Click to download.

- Fig.1S.pdf

- Fig.2S.pdf

- Fig.3S.pdf

- Fig.4S.pdf

- Fig.5S.pdf

- Fig.6S.pdf

- Fig.7S.pdf

- Fig.8S.pdf

- Fig.9S.pdf 